\begin{tabular}{|c|l|}
\hline Title & $\begin{array}{l}\text { Geology and stratigraphy of forearc basin sediments in Hokkaido, Japan: Cretaceous environmental events on the north- } \\
\text { west Pacific margin }\end{array}$ \\
\hline Author(s) & Takashima, Reishi; Kawabe, Fumihisa; Nishi, Hiroshi; Moriya, Kazuyoshi; W ani, Ry oji; A ndo, Hisao \\
\hline Citation & $\begin{array}{l}\text { Cretaceous Research, 25(3), 365-390 } \\
\text { https://doi.org/10.1016/.cretres.2004.02.004 }\end{array}$ \\
\hline Issue Date & 200406 \\
\hline Doc URL & http://hdl.handle.net/2115/17182 \\
\hline Type & article (author version) \\
\hline File Information & CR25-3.pdf \\
\hline
\end{tabular}

Instructions for use 


\section{Geology and stratigraphy of forearc basin sediments in Hokkaido, Japan: Cretaceous environmental events on the Northwest Pacific margin}

\footnotetext{
${ }^{a}$ Reishi Takashima*, ${ }^{b}$ Fumihisa Kawabe, ${ }^{a}$ Hiroshi Nishi, ${ }^{c}$ Kazuyoshi Moriya, ${ }^{d}$ Ryoji Wani and ${ }^{\mathrm{e}} \mathrm{Hisao}$ Ando
}

a Department of Earth and Planetary Science, Graduate School of Science, Hokkaido University, N10W8, Kita-ku, Sapporo, 060-0810, Japan

b Institute of Natural History, 3-14-24 Takada, Toshima-ku, Tokyo 171-0033, Japan

c Department of Earth Science, Graduate School of Social and Cultural Studies, Kyushu University, 4-2-1, Ropponmatsu, Chuo-Ku, Fukuoka, 810-8560, Japan

d Department of Geology, National Science Museum, 3-23-1, Hyakunincho, Shinjuku-ku, Tokyo, 169-0073 Japan

e Department of Environmental Sciences, Faculty of Science, Ibaraki University, 2-1-1, Bunkyo, Mito, 310-8512, Japan

* corresponding to: E-mailaddress:rtaka@nature.sci.hokudai.ac.jp. 


\begin{abstract}
Litho-, bio-, and chemostratigraphy of the Cretaceous forearc basin sediments exposed in Hokkaido, northern Japan allow a synthesis of the faunal, sedimentological, and environmental history of the north-west Pacific margin.
\end{abstract} Although the succession, named the Yezo Group, has yielded an abundant record of mid- to late Cretaceous invertebrates, a monotonous lithology of sandstone and mudstone, showing occasional lateral facies change, has caused confusion regarding the lithostratigraphic nomenclature. Based on our wide areal mapping of the sequence, and analysis of litho- and biofacies, a new lithostratigraphic scheme for the Yezo Group is proposed. In ascending order, the scheme is as follows: the Soashibetsugawa Formation (Lower Aptian mudstone unit); the Shuparogawa Formation (Lower Aptian-lower Upper Albian sandstone-dominant turbidite unit); the Maruyama Formation (lower Upper Albian tuffaceous sandstone unit); the Hikagenosawa Formation (Upper Albian-Middle Cenomanian mudstone-dominant unit); the Saku Formation (Middle Cenomanian-Upper Turonian sandstone-common turbidite unit); the Kashima Formation (Upper Turonian-Lower Campanian mudstone-dominant unit); and the Hakobuchi Formation (Lower Campanian-Palaeocene shallow-marine sandstone-conglomerate unit). In addition, we designate two further lithostratigraphic units, the Mikasa Formation (Upper Albian-Turonian shallow-marine sandstone-dominated unit) and the Haborogawa Formation (Middle Turonian-Campanian shelf mudstone/sandstone unit), which correspond to the autochronous pairs of the shallower facies of the Saku and 
Kashima formations, respectively.

Despite lack of so-called 'black shales', because of siliciclastic dilution, our stratigraphic integration has revealed the horizon of oceanic anoxic events (OAEs) in the Yezo Group. OAE1a horizon in the Soashibetsugawa Formation is characterized by a lack of foraminifers, macrofossils and bioturbation, and a prominent positive excursion of $\delta^{13} \mathrm{C}_{\mathrm{org}}$. A significant hiatus during the late Aptian and early Albian removed OAE1b horizon. OAE1c horizon in the Maruyama Formation shows a distinct negative excursion of $\delta^{13} \mathrm{C}_{\mathrm{org}}$ with a concomitant high productivity of radiolarians. OAE1d horizon in the middle part of the Hikagenosawa Formation consists of weakly-laminated, pyrite-rich mudstone. Planktonic and calcareous benthic foraminifers are absent, whereas radiolarians are abundant above OAE1d horizon. The mid-Cenomanian event (MCE) horizon is identified at the top of the Hikagenosawa Formation. Step-wise extinction of calcareous benthic foraminifers and a decrease in radiolarian diversity become apparent above the MCE horizon. In the study area, OAE2 horizon has been well documented, and is placed in the middle part of the Saku Formation.

Keywords: Cretaceous; stratigraphy; Yezo Group; OAEs; Pacific; forearc basin 


\section{Introduction}

Knowledge of Cretaceous ocean-climate systems provides important information to help understand a future warm greenhouse world. In particular, the mid-Cretaceous warming around 120-90Ma, enhanced by a huge production of oceanic crust and plateaus in the Pacific and Indian Oceans, brought higher levels of greenhouse gases and high poleward heat transportation (e.g., Larson, 1991a, b). This global warming induced an unique deep-ocean circulation and expansion of anoxic conditions, known as oceanic anoxic events (OAEs) that resulted in large turnovers of marine biota (Leckie et al., 2002). Many palaeontological and geochemical studies of OAEs have been conducted in land sections across the Tethyan region (e.g., Erbacher et al., 1996), on deep-sea cores from the Atlantic (e.g., Bralower et al., 1994; Wilson and Norris, 2001), the Antarctic (e.g., Bralower et al., 1993), and from equatorial Pacific regions (e.g., Sliter, 1989), whereas there is little information about Cretaceous environmental events in the North Pacific.

The Cretaceous Yezo Group, exposed in central Hokkaido, northern Japan, was probably deposited at about $35-45^{\circ} \mathrm{N}$ (Hoshi and Takashima, 1999; Kodama et al., 2002) along a westward subduction margin in the north-eastern Asian continent during the Cretaceous. This group consists of a $10000-m-t h i c k$ forearc sedimentary sequence of sandstones and mudstones with subordinate conglomerates. This forearc basin is called the Yezo Basin (Okada, 1983), extending from offshore of north Honshu, through Hokkaido, to Sakhalin Island, Russia (Fig. 1). As the rocks contain 
abundant, well-preserved macro- and microfossils, many biostratigraphic schemes have been established (Matsumoto, 1942, 1977; Tanaka, 1963; Obata and Futakami, 1975, Futakami, 1982, Taketani, 1982; Maeda, 1986, Toshimitsu and Maiya, 1986; Motoyama et a1., 1991; Kawabe et al., 1996, 2003; Takashima et al., 1997; Toshimitsu et a1., 1998; Kawabe, 2000; Wani and Hirano., 2000; Moriya and Hirano, 2001; Ando et al., 2001; Nishi et a1., 2003). In the last decade, carbon isotope excursions of organic materials have also been reported across the Cenomanian/Turonian boundary (OAE2) and from the upper Lower Aptian (Hasegawa and Saito, 1993; Hasegawa, 1995, 1997; Ando et a1., 2002, 2003). Moreover, the thermal structure of the north-western Pacific of the Asian continental margin has recently been investigated, based on oxygen isotopic analyses (Moriya et al., 2003). These studies provide important information of Cretaceous environmental change and faunal turnover related to global events in the mid-latitude north-west Pacific.

However, the nomenclature of the lithostratigraphic divisions in the Yezo Group are complicated and differ between the investigated areas within Hokkaido, and several names have been used synonymously for the same lithostratigraphic unit. We, therefore, propose here a new, synthesized stratigraphic framework, including macro- and microfossil biostratigraphy, based on extensive mapping of the entire area in the central region of Hokkaido. Moreover, we organize the stratigraphic and geographic distribution of OAE horizons recorded in the Yezo Group using the new standard stratigraphy. 


\section{Geological setting}

The Jurassic to Palaeogene sequences exposed in the western and central parts of Hokkaido, northern Japan, are basically divided into three $\mathrm{N}-\mathrm{S}$ trending tectono-stratigraphic divisions called the Oshima (Cretaceous volcanic arc on a Jurassic accretionary complex), the Sorachi-Yezo (Cretaceous-Palaeocene forearc basin and accretionary complex), and the Hidaka (lower Palaeogene accretionary complex) belts from west to east (Kiminami et al., 1986; Ueda et al., 2000) (Fig. 1). These were formed along a westward-dipping subduction of the Izanagi-Kula Plates under the eastern margin of the Asian continent (e.g., Okada, 1974).

The Sorachi-Yezo Belt consists of a coherent succession, from the Horokanai Ophiolite through the Sorachi Group to the Yezo Group (Fig. 2), and the accretionary complexes of the Idonnapu and Kamuikotan zones (Ueda et al., 2000; Fig. 1). The Horokanai Ophiolite and the lower part of the Sorachi Group represent a piece of basaltic oceanic crust (Ishizuka, 1981; Takashima et al., 2002a), while the upper part of the Sorachi Group is represented by subaqueous calc-alkaline and alkaline volcano-sedimentary sequences, suggesting an oceanic island arc setting (Girard et al., 1991; Niida, 1992; Takashima et al., 2002b). The Yezo Group conformably overlies the Sorachi Group and comprises very thick sandstone and mudstone sequences. The sand clastics of this sequence were derived from Cretaceous granitic rocks and Jurassic accretionary complexes of the Oshima Belt, 
which represents a contemporaneous continental arc setting (Kito et al., 1986). Although a part of the Hakobuchi Formation includes the upper Palaeocene in the Oyubari and Nakatonbetsu areas (Ando et a1., 2001; Ando, 2003), the geological age of this formation ranges mostly from early Aptian to early Maastrichtian. Many hiatuses exist between the Campanian and Maastrichtian. The sedimentary environment of this group shows an eastward-deepening facies trend, from fluvial to continental slope (Fig. 2). The Yezo Group is unconformably capped by late Eocene, non-marine and shallow-marine sediments of the Ishikari and Poronai Groups, or by younger Neogene deposits.

Fig. 2 near here

\section{Stratigraphy of the Yezo Group}

Lithostratigraphic nomenclature for the Yezo Group is very confused. Various definitions have been proposed, depending on the area and the researchers, because this group basically consists of a monotonous sequence of sandstone and mudstone and their alternating beds, which occasionally exhibit lateral facies changes. The criteria of lithological boundaries have been defined by sandstone intercalations and/or detailed changes of the sandstone/mudstone ratios in alternating beds. However, our study reveals that the Yezo Group throughout Hokkaido is basically characterized by six alternations of mudstone-dominant units and sandstone-common units, with intercalations of six distinct stratigraphic key units (Fig. 2, Table 1). The revised lithostratigraphic definitions proposed in this 
paper are as follows, in ascending order (Figs. 2, 3): the Soashibetsugawa Formation (mudstone unit); the Shuparogawa Formation (sandstone-dominant turbidite unit); the Maruyama Formation (felsic tuff and tuffaceous sandstone unit); the Hikagenosawa Formation (mudstone-dominant unit); the Saku Formation (sandstone-common turbidite unit); the Kashima Formation (mudstone unit) and the Hakobuchi Formation (shallow-marine sandstone unit).

We also recognize the sandstone-dominant, outer-shelf to shoreface Mikasa Formation and the overlying, sandy mudstone-dominant outer-shelf Haborogawa Formation. The former is exposed in the Mikasa area, and the latter in the Tomamae and Mikasa areas (Figs. 2, 4, 5). The geological ages of these formations correspond to the Saku and the Kashima Formations exposed in the Oyubari area, respectively (Fig. 2). Additionally, in the study areas we name six stratigraphic key units as KY-1 to KY-6 consisting of olistostrome (KY-1), tuffaceous sandstone (KY-2, KY-4 to 6), and sandstone-conglomerate units (KY-3) (Fig. 2, Table 1).

-Table 1, Fig. 3 near here

\subsection{Soashibetsugawa Formation (redefine)}

Definition. This formation is characterized by a predominance of dark grey siliceous mudstone, and corresponds to the Soashibetsugawa Mudstone Member of the Shuparogawa Formation of Takashima et al. (2001) (Fig. 3). Takashima et al. (2001) 
defined the member as the basal unit of the Yezo Group because of the lithofacies shift from in situ volcanic and volcaniclastic rocks of the Sorachi Group to terrigenous, dark grey mudstone at the base of the member. As the member is widely traceable and clearly distinguishable from other members (sandstone-dominant facies) of the Shuparogawa Formation of Takashima et al. (2001), we redefine the member as the basal formation of the Yezo Group.

Stratigraphic relationship. This formation conformably overlies the Shirikishimanaigawa Formation of the Sorachi Group.

Type-section. The Soashibetsu River section, northern Oyubari area (Figs. 4, 6: section 11).

Lithology. The formation consists of dark grey parallel-laminated mudstone with many intercalations of felsic tuff beds (Fig. 7A). The laminae are composed of felsic tuff and very fine-grained sand layers. Deep-sea trace-fossils, such as Lorenzinia and Cosmorhaphe are found occasionally in the mudstone. The tuff beds are white, hard and generally $10-30 \mathrm{~cm}$ thick, though some beds attain a thickness of 1-7 $\mathrm{m}$. They contain fine-grained, bubble-wall glass shards with minor amounts of idiomorphic feldspar and biotite.

Thickness and distribution. The formation is $450-700 \mathrm{~m}$ thick in the eastern part of 
the Oyubari area, and not exposed in the Mikasa and Tomamae areas.

Fossils and age. No macrofossils have been found from this formation. Radiolarians occur abundantly throughout the sequence of this formation, but there are no age-diagnostic species. Planktonic foraminifers appear rarely in the upper part of the formation (Fig. 8). The early Aptian species, Leupoldina cabri (Sigal), occurs from the uppermost part of this formation (Saito and Ando, 2000; Takashima et al., 2001; Nishi et al., 2003). Agglutinated benthic foraminifers, such as Bathysiphon, also occur occasionally.

Depositional environment. Microfossil assemblages and deep-sea trace fossils suggest an abyssal environment.

\subsection{Shuparogawa Formation (redefine)}

Definition. This formation, corresponding to the Tomitoi and Shuparogawa Formations of Motoyama et al. (1991), is distinguished from the mudstone-dominant Soashibetsugawa Formation by the onset of common to frequent intercalations of sandstone beds.

Type-section. Along the Shuparo River section, the central Oyubari area (Figs. 4, 6: section 12). 
Stratigraphic relationships. The Shuparogawa Formation conformably overlies the Soashibetsugawa Formation in the Oyubari area, while the basal part of this formation is not exposed in the Tomamae and Mikasa areas because of poor exposure.

Lithology. The Shuparogawa Formation is mainly composed of alternating beds of turbiditic sandstone and dark grey mudstone. This formation incorporates a thick olistostrome bed (Kirigishiyama Olistostrome Member) in the middle portion, and is subdivided into three members as follows: the Refureppu Sandstone, Kirigishiyama Olistostrome, and Okusakainosawa Sandstone and Mudstone members, in ascending order (Figs. 2, 6).

The Refureppu Sandstone Member consists of a very thick- to medium-bedded, sandstone-dominant sequence in the lower part (Fig. 7B) and thin to very thin-bedded, mudstone-dominant alternating beds in the upper part. It locally contains slump beds. Lower sandstones are stratified, well sorted, usually ranging from 10 to $50 \mathrm{~cm}$ thick, and occasionally more than $1 \mathrm{~m}$ thick. They are turbidites showing the $\mathrm{S}_{3}-\mathrm{T}_{\mathrm{b}-\mathrm{e}}$ divisions of Lowe (1982), with many sole marks. The sandstone/mudstone $(\mathrm{S} / \mathrm{M})$ ratio in the lower part is about 5/1. Sandstones in the upper part are less than $5 \mathrm{~cm}$ thick, with $\mathrm{T}_{\mathrm{c}-\mathrm{e}}$ divisions, and the $\mathrm{S} / \mathrm{M}$ ratio is $1 / 2$ to 1/5. Mudstones in this member are uniformly less than $10 \mathrm{~cm}$ thick, dark grey and weakly bioturbated. In the northern Oyubari area, this member is dominated by 
sandstone throughout (Fig. 6: section 11).

The Kirigishiyama Olistostrome Member represents an olistostrome bed containing huge allochthonous blocks of massive sandstone $(<40 \mathrm{~m}$ thick $)$, alternating beds of sandstone and mudstone $(<20 \mathrm{~m}$ thick $)$ and limestone $(<60 \mathrm{~m}$ thick) in a muddy matrix (Fig. 7C). Limestone olistoliths consist of coral, large foraminifers (Orbitolina), rudists and ooids, contaminated with pebbles of chert, granite and sandstone. The width and thickness of limestone olistoliths is greatest in the northern Oyubari area where a 60 -m-thick, slab-shaped block is continuously exposed for a distance of $3 \mathrm{~km}$ in a $\mathrm{N}-\mathrm{S}$ direction (Fig. 4, around Mt. Kirigishiyama). The limestone olistoliths thin out in the Tomamae and southern Oyubari areas. However, the olistostrome bed is widely traceable throughout the study area as a key unit (KY-1) (Fig. 6).

The Okusakainosawa Sandstone and Mudstone Member basically comprises mudstone-dominant alternating beds, and varying thicknesses of sandstone, from 5 to $50 \mathrm{~cm}$ depending on the area (Fig. 7D). Sandstones are turbiditic, exhibiting $\mathrm{T}_{\mathrm{b}-\mathrm{e}}$ sequences with sole marks and numerous plant fragments, while thick sandstones show the $\mathrm{S}_{1-3}$ divisions of Lowe (1982). In the Oyubari area, intercalations of sandstone become common to abundant in the middle part of this member (Fig. 6: section 11). Mudstones are bioturbated with moderate numbers of trace fossils.

Thickness. The formation is approximately $1500 \mathrm{~m}$ thick in the type-section. However, it exhibits various thicknesses, ranging from 800 to $2450 \mathrm{~m}$. 
Fossils and age. Mudstones of the Refureppu Sandstone Member yield a few foraminifers and common radiolarians, but no macrofossils (Fig. 8). Planktonic foraminifers include the Upper Aptian species, Globigerinelloides barri (Bolli, Loeblich and Tappan) and G. duboisi (Chevalier). Agglutinated and calcareous benthic foraminifers also occur occasionally. The Okusakainosawa Sandstone and Mudstone Member contains abundant radiolarians and planktonic foraminifers, with a subordinate proportion of common agglutinated and calcareous benthic foraminifers. The Upper Albian ammonoid, Mortoniceras cf. geometricum Spath, occurs in the upper part of this member (Kawabe, 2000). This member also includes the transitional interval from the Ticinella primula planktonic foraminifera (pf) zone to the lower part of the Biticinella breggiensis pf zone, assigned to the Lower-lower Upper Albian (Nishi et al. 2003) (Fig. 8). A significant hiatus is present from the Planomalina cheniourensis to Hedbergella planispira zones of Hardenbol et al. (1998), approximately 115.5-108.21 Ma (7 myr). It might have been eroded by deposition of the Kirigishiyama Olistostrome Member. The limestone olistoliths yield larger foraminifers of orbitolinids, e.g., Orbitolina lenticularis (Blumenbach), and its age is assigned as Late Aptian-Early Albian (Matsumaru, $1971)$.

Depositional environment. Lithology and benthic foraminiferal data suggest this formation was deposited on the continental slope (e.g., Motoyama et al., 1991). 
Benthic foraminifers of the Refureppu Sandstone Member and the Okusakainosawa Sandstone and Mudstone Member, consisting of species of Bathysiphon, Gaudryina, Gyroidinoides, Gavelinella and Nodosaria, indicate the upper bathyal zone or deeper (e.g., Sliter and Baker, 1972). However, the limestones of the Kirigishiyama Olistostrome Member are considered to have been formed on a carbonate platform, such as a rimmed shelf along the Asian continental margin (Sano, 1995). The olistostrome indicates the collapse of the shallow carbonate platform and mixing with the bathyal mudstone around the Aptian/Albian boundary.

Fig. 4 near here

\subsection{Maruyama Formation}

Definition. The formation is defined by an assemblage of hard felsic volcaniclastic sandstones, tuffs and associated conglomerates (Motoyama et al., 1991) (Fig. 3). This formation also provides an excellent stratigraphic marker (KY-2), extending throughout Hokkaido (Table 1).

Type-section. Along the Shuparo River section, central Oyubari area (Figs. 4, 6: section 12).

Stratigraphic relationship. This formation conformably overlies the Shuparogawa Formation. 
Lithology. This formation is composed of tuffaceous sandstone beds (Fig. 7E), locally accompanied by conglomerates at the base. The tuffaceous sandstone beds are $0.3-2 \mathrm{~m}$ thick, white to pale brown, siliceous and very hard. These beds have turbiditic features of graded to parallel-laminated sequences $\left(T_{b-e}\right)$ and basal rip-up mudstone clasts. Microscopically, the sandstones are composed of platy glass shards, subordinate idiomorphic plagioclase, biotite, quartz and hornblende. The tuffaceous unit varies from 4 to $84 \mathrm{~m}$ thick throughout the study area.

The conglomerates accompanying the base of this formation are usually less than $2 \mathrm{~m}$ thick. However, in the central part of the Tomamae area, the total thickness of the conglomeratic beds exceptionally attains as much as $900 \mathrm{~m}$ (Fig. 6: section 10). The conglomerates are thick-bedded, poorly sorted, and clast-supported, structureless or exhibiting $\mathrm{R}_{3}-\mathrm{S}_{1}$ divisions of Lowe (1982). The conglomerates consist mainly of subrounded pebbles-to-boulders of rhyolite, with subordinate, well-rounded granules to pebbles of mudstone, chert and siliceous mudstone in the Tomamae area, whereas in the Oyubari area they are composed of granules to pebbles of chert, sandstone, siliceous mudstone and limestone.

Thickness. This formation attains thicknesses of $180-900 \mathrm{~m}$ in the Tomamae area and 4-84 $\mathrm{m}$ in the Oyubari area. The horizon and thickness of this formation are disputable in the Mikasa area because of poor exposure. 
Fossils and age. Although no planktonic foraminifers and macrofossils have been obtained from this formation, radiolarians (spumellarians) occur abundantly (Fig. $8)$.

Depositional environment. Abundant volcaniclastic materials in this formation suggest that huge, felsic volcanic eruptions episodically occurred along the western circum-Pacific/Asian continental margin. Main transporting channels for the volcanic sediments are inferred to have been located in the Tomamae area.

Fig. 5 near here

\subsection{Hikagenosawa Formation}

Definition. This formation is defined by the predominance of dark grey mudstone (Motoyama et al., 1991; Fig. 3), although there are intercalations of a thin sandstone-dominant unit (Kanajiri Sandstone Member) in the lower middle part.

Type-section. Along the Hikageno-sawa Valley section, the central Oyubari area (Fig. 4).

Stratigraphic relationship. The formation overlies, conformably, the Maruyama Formation. 
Lithology. The dominant lithology of the Hikagenosawa Formation is dark grey mudstone (Figs. 6, 8F). A thin unit of alternating beds of sandstone/conglomerate and mudstone (Kanajiri Sandstone Member) is intercalated in the lower middle part of this formation. This unit is used as a stratigraphic marker, the KY-3 (Fig. 2, Table $1)$.

The lower part of this formation is characterized by weakly-laminated mudstone. The intercalations of thin-bedded felsic tuffs and distal turbiditic sandstones showing $\mathrm{T}_{\mathrm{c}-\mathrm{e}}$ divisions are common in the Tomamae and Mikasa areas. In the northern Tomamae area, thick- to very thick-bedded sandstones with $\mathrm{S}_{3}-\mathrm{T}_{\mathrm{b}-\mathrm{e}}$ are also intercalated, exceptionally (Fig. 6: section 9). On the other hand, rare sandstones are intercalated in the Oyubari area. Mudstones in the upper part of this formation are moderately bioturbated, and occasionally weakly-laminated.

The Kanajiri Sandstone Member is composed of thick- to very thick-bedded, sandstone with very thick-bedded conglomerates in the Tomamae area, whereas this member in the Oyubari area is thin- to medium-bedded, mudstone-dominant alternating beds of sandstone and mudstone (Fig. 7G). Sandstones are proximal $\left(\mathrm{S}_{3}-\mathrm{T}_{\mathrm{b}-\mathrm{e}}\right)$ in the former area and distal $\left(\mathrm{T}_{\mathrm{d}-\mathrm{e}}\right)$ in the latter. The conglomerates are well-rounded, pebbles to granules, exhibiting $\mathrm{R}_{3}-\mathrm{S}_{1}$ dibisions. Their compositions are mostly chert with minor sandstone, mudstone and igneous rocks. The horizon and thickness of this member are disputable in the Mikasa area because of poor exposure and scarce fossil data. 
Thickness and distribution. 1900-2600 m thick in the Oyubari area, and 1900-2000 $m$ thick in the Tomamae area. The thickness in the Mikasa area is uncertain because of poor exposure.

Fossils and age. The occurrence of macrofossils (ammonoids and inoceramids) becomes common above the lower part of this formation (Fig. 8). The late Albian-middle Cenomanian ammonoids Mortoniceras rostratum (Sowerby), Mariella bergeri (Brongniart), Mantelliceras saxbii (Sharpe) and Cunningtoniceras cunningtoni (Sharpe) occur in the formation. Microfossils are abundant throughout the sequence. Exceptionally, planktonic foraminifers and calcareous benthic foraminifers are lacking around the Kanajiri Sandstone Member, whereas radiolarians become very abundant and agglutinated benthic foraminifers are common in this interval (Fig. 8). Planktonic foraminifers indicative of the Biticinella breggiensis to Rotalipora cushmani pf zones, for example, Biticinella breggiensis (Gandolfi), Ticinella subticinensis (Gandolfi), Rotalipora appenninica (Renz), R. globotruncanoides Sigal, and R. cushmani (Morrow), occur, indicating a Late Albian to Late Cenomanian age (Nishi et al., 2003; Fig. 8).

Depositional environment. Benthic foraminiferal assemblages suggest this formation was deposited in the lower part of the upper bathyal zone under relatively oxygenated conditions (Motoyama et al., 1991; Kaiho et al., 1993). 


\subsection{Saku Formation}

Definition. This formation is defined by the frequent intercalations of turbiditic sandstone beds (Matsumoto, 1942).

Type-section. The Abeshinai River section, Teshionakagawa area, northern Hokkaido (Fig. 1). Lithology and distribution of this formation were well documented by Matsumoto (1942) and Matsumoto and Okada (1972).

Stratigraphic relationship. The formation overlies conformably the Hikagenosawa Formation.

Lithology. This formation comprises alternating beds of turbiditic sandstone and mudstone, and intercalates with a unit characterized by a predominance of greenish-grey muddy sandstones (Hakkin Muddy Sandstone Member; KY-4) in the middle part (Fig. 2, Table 1).

Sandstones in the lower part (below the KY-4) are less than $40 \mathrm{~cm}$ thick and exhibit typical turbiditic sequences, having $\mathrm{T}_{\mathrm{b}-\mathrm{e}}$ divisions. Mudstones are dark grey-coloured and moderately bioturbated. The $\mathrm{S} / \mathrm{M}$ ratios change from $1 / 10$ to $1 / 1$ (Fig. $7 \mathrm{H})$.

A very characteristic lithofacies, greenish grey muddy sandstone with abundant trace-fossils of Planolites (Fig. 7I), is observable in the middle part of this 
formation. This greenish unit extends from the Oyubari area to the central Tomamae area, about $200 \mathrm{~km}$, and is defined as the KY-4 (the Hakkin Muddy Sandstone Member). The member incorporates medium-/thick-bedded sandstones, with $\mathrm{S}_{3}-\mathrm{T}_{\mathrm{b}-\mathrm{e}}$ divisions, and frequent felsic tuff beds. The tuff beds vary in thickness from 0.02 to $2 \mathrm{~m}$, and are altered to bentonites. Finely laminated, pyrite-rich, dark grey-greyish black mudstones are intercalated just below or in the lower part of this member in the Oyubari and Tomamae areas.

The upper part of the formation begins with dark grey mudstone and changes to alternating beds of sandstone and mudstone. Sandstones are thin- to medium-bedded turbidites with $\mathrm{T}_{\mathrm{b}-\mathrm{e}}$ sequences, and the $\mathrm{S} / \mathrm{M}$ ratios are not high, $1 / 10$ to $1 / 5$. Slump beds and sandstone dykes are common in the southern Oyubari area. Sandstones are occasionally intensively bioturbated and bedding planes of some beds are destroyed. Mudstones and sandy mudstone are dark grey- to grey-coloured and intensively bioturbated.

On the other hand, the Saku Formation, exposed in the northern Tomamae area, is marked by four thinning-upward sequences (Fig. 6: section 8). A channel-filling conglomerate/sandstone unit constitutes the first and third sequence. The conglomerates are clast-supported, and $0.5-4 \mathrm{~m}$ thick, with disorganized erosional bases (Fig. 7J). Graded bedding, from well-rounded cobble to coarse sandstone $\left(\mathrm{R}_{2-3}-\mathrm{S}_{1}\right.$ divisions $)$, is common. The sandstones are very thick-/thick-bedded, showing $\mathrm{S}_{1}-\mathrm{T}_{\mathrm{b}-\mathrm{e}}$ divisions. The second and fourth cycles show the facies changes from very thick-/thick-bedded, sandstone-dominant alternating 
beds to thin-bedded mudstone-dominant ones. The sandstones are proximal turbidites, exhibiting $\mathrm{S}_{1}-\mathrm{T}_{\mathrm{b}-\mathrm{e}}$ divisions.

Thickness and distribution. $2300 \mathrm{~m}$ in the Oyubari area, 1800-2000 $\mathrm{m}$ in the Tomamae area. The upper part of this formation is truncated by the $\mathrm{N}-\mathrm{S}$ trending thrust fault (Kashima Thrust Fault) in the northern Oyubari area (Fig. 4).

Fossils and age. The formation bears abundant macrofossils, except the Hakkin Muddy Sandstone Member (Fig. 8). The Cenomanian ammonoids, Calycoceras spp., occur in the lower part of the formation. The blackish grey mudstone intercalated in the basal part of the Hakkin Muddy Sandstone Member is correlated with the Cenomanian/Turonian boundary, based on the results of carbon isotope, mega- and microfossil stratigraphy (e.g., Hasegawa and Saito, 1993; Hirano, 1995). Although macrofossils are few in the Hakkin Muddy Sandstone Member, the Lower Turonian indicators, such as Pseudaspidoceras flexuosus (Powell) and vascoceratids, occur. The upper sequence is marked by an abundant occurrence of heteromorphic ammonoids, including Nipponites, Eubostrichoceras and scaphitids, with minor Middle Turonian indicators, such as Romaniceras spp. (ammonoid) and Inoceramus hobetsensis Nagao and Matsumoto (bivalve). Microfossils commonly occur throughout the sequence; radiolarians are especially abundant in the Hakkin Muddy Sandstone Member, and occupy 80-90\% of the total. This formation ranges from the Rotalipora cushmani to Helvetoglobotruncana helvetica $\mathrm{pf}$ zones, assigned to the 
Upper Cenomanian-Middle Turonian (Nishi et al., 2003; Fig. 8).

Depositional environment. The benthic foraminiferal assemblages indicate the lower part of upper bathyal depth-zone with relatively low-oxygen conditions (Kaiho et al., 1993).

Fig. 6 near here

\subsection{Mikasa Formation}

Definition. This formation is the contemporaneous, shallower facies of the Saku Formation, and is defined by the predominance of sandstones exhibiting hummocky and trough cross-stratification (Matsumoto, 1951; Ando, 1990a).

Type-section. North-west of Katsurazawa Lake, in the eastern Mikasa area (Fig. 4).

Lithology. The Mikasa Formation is characterized by a predominance of sandstones with hummocky and trough cross-stratification (HCS and TCS) and gravel/shell lags, and intensively bioturbated sandy mudstone (Fig. 7K). This formation is divided into three coarsening-upward successions, assigned as third-order depositional sequences $\left(D_{1}, D S_{2}\right.$ and $\left.D S_{3}\right)$, each of which further includes three fourth-order sequences (4th DS) (Ando, 1997), Within each DS, conglomerate and coarse-grained sandstone tend to thicken in the west, and interbedded, sandy mudstone becomes 
dominant and thick in the east.

In the northwestern Mikasa area, the $\mathrm{DS}_{1}$ begins with alternating beds of turbiditic sandstone and mudstone, and grades into HCS sandstone with bioturbated, very fine-grained sandstone/sandy mudstone. A basal thick, cross-stratified conglomerate of the $\mathrm{DS}_{2}$ covers HCS sandstones of $\mathrm{DS}_{1}$ with a sharp erosional base (unconformity) (Fig. 6: section 1). The $\mathrm{DS}_{2}$ comprises a wide variety of lithofacies, such as cross-stratified conglomerate, carbonaceous mudstone, sandy mudstone with oyster-shell beds, medium- to coarse-grained sandstone with TCS, HCS fine sandstone and bioturbated sandy mudstone. The $\mathrm{DS}_{3}$ deposits are distributed in the southern Mikasa area, mainly comprising bioturbated, sandy mudstone and HCS sandstones. The intercalations of HCS sandstone become frequent in the upper part of each 4th DS. This DS grades into the Saku Formation northward and eastward.

Thickness and distribution. This formation is exposed only in the Mikasa area, forming the Sorachi-Ikushunbetsu Anticline and the Manji and Hatonosu Domes. Its thickness ranges from 400 to $750 \mathrm{~m}$, and tends to thicken eastward.

Fossils and age. Shallow-marine bivalves (including Apiotrigonia, Glycymeris, Meekia, Pinna, Pseudoptera, Pterotorigonia, Thetis, Yaadia), gastropods (e.g., Margarites, Semisolarium) occur as storm-lag deposits within HCS sandstones. Bioturbated, muddy sandstones to sandy mudstones contain rare to common ammonoids and inoceramids, but no microfossils. The Cenomanian ammonoids, 
Mantelliceras sp., Calycoceras sp. and Desmoceras spp. have been reported from the $\mathrm{DS}_{1}$ deposits (Kawabe, 2003). The Turonian species, Inoceramus hobetsensis and Inoceramus teshioensis $\mathrm{Nagao}$ and Matsumoto, are abundant in bioturbated sandy mudstones of $\mathrm{DS}_{2}$ and $\mathrm{DS}_{3}$, respectively (Ando, 1990a, b).

Depositional environment. Three DSs show conspicuous lateral and vertical facies changes, representing repetitive delta progradations in the western margin of the Yezo Basin. Judging from the stacking patterns of their facies, 3rd-and 4th-order DSs, the delta system is presumed to have shifted southward within the distribution area (Ando, 1997, 2003). The depositional environment of the $\mathrm{DS}_{1}$ deposits is interpreted as basin-plain on continental slope to lower shoreface through shelf. The $\mathrm{DS}_{2}$ represents non-marine to shallow-marine environments, such as fluvial channel, back marsh, flood plain and tidal flat in the lower part, followed by deeper marine (shoreface to inner shelf, though partly outer shelf) in the upper. The $\mathrm{DS}_{3}$ is thought to have been deposited from lower shoreface to outer shelf environments.

\subsection{Kashima Formation}

Definition. The formation is defined by the predominance of dark grey, massive mudstone overlying the Saku Formation (Motoyama et al., 1991; Fig. 3).

Type-section. Kashima village in the southern Oyubari area (Fig. 4). 
Stratigraphic relationship. This formation covers, conformably, the Saku Formation.

Lithology. This formation consists mainly of dark grey, bioturbated, massive mudstone (Fig. 7L), grading into muddy sandstones in the uppermost part. The mudstones are intercalated with two felsic volcaniclastic units, in the lower and middle parts, respectively. The lower volcaniclastic unit is $10-20$ m thick, consisting of thick-bedded, coarse- to fine-grained, volcaniclastic sandstones with interbedded dark grey mudstones. The sandstone beds are turbiditic with $T_{b-e}$ divisions, and less than $2 \mathrm{~m}$ thick, rarely attaining $4 \mathrm{~m}$ thick in the northern Oyubari area. The thickness of the mudstones is variable, depending on the area, but all are less than $2 \mathrm{~m}$ thick. A diagnostic feature of this unit is abundant occurrences of Inoceramus uwajimensis Yehara from the interbedded mudstone (Fig. 7M). This unit is an excellent stratigraphic marker (K Y-5) throughout the study areas (Table 1).

Compared with the lower unit, the upper volcaniclastic unit differs in lacking mudstone intercalations and macrofossils. Tuffaceous sandstones or tuffs are thick-bedded $(<1 \mathrm{~m}$ thick), white-coloured, coarse- to very fine-grained. Some are altered to bentonite.

Thickness. About $1670 \mathrm{~m}$ in the southern Oyubari area. The thickness of this formation in the northern Oyubari area is difficult to estimate because of 
monotonous lithology and complex geological structure, with isoclinal folding and thrust faulting.

Fossils and age. This formation contains abundant calcareous concretions, including macrofossils such as ammonoids and inoceramids. I. uwajimensis is particularly abundant in the KY-5 unit (Fig. 8).

Microfossils (foraminifers and radiolarians) are abundant, although Tethyan marker-species are very rare. The following four mid-latitude zones of planktonic foraminifers, therefore, have been proposed from the Late Turonian to Campanian in the study area: the Marginotruncana pseudolinneana; M. sinuosa; Contusotruncana fornicata; and Globotruncana arca pf zones (Fig. 8). These can be correlated directly with the Tethyan planktonic foraminiferal zones (Nishi et al., $2003)$.

Depositional environment. Benthic foraminiferal assemblages indicate the upper part of the upper bathyal depth under relatively medium- to high-oxygen conditions (Kaiho et a1., 1993).

\subsection{Haborogawa Formation (new)}

Definition. The base of this formation is defined as bioturbated mudstone without sandstone intercalations, overlying the Saku Formation. While the lower part of this 
formation is mainly composed of bioturbated mudstone, the upper part is characterized by coarsening upward successions, from mudstone to muddy sandstone and/or sandstone.

Type-section. The Nakafutamata River section, in the northern Tomamae area (Figs. 5, 6: section 7).

Stratigraphic relationships. The formation is exposed in the Tomamae and Mikasa areas, and conformably covers the Saku and Mikasa formations, respectively. This formation is the synchronous shallower-water facies of the Kashima Formation.

Lithology. The lithology and sedimentary cycles of this formation differ between the Tomamae and Mikasa areas.

This formation in the Mikasa area forms a single, coarsening-upwards sequence, from bioturbated sandy mudstone to very fine-grained sandstone. Two felsic volcaniclastic turbidite units of the KY-5 and KY-6 (Tsukimi Sandstone Member) are intercalated in the lower and middle parts, respectively. The KY-5 unit consists of thick beds of volcaniclastic sandstones with abundant Inoceramus uwajimensis. In the Tsukimi-sawa Valley section, the KY-5 becomes channel-fill conglomerates, including well-rounded pebbles of chert, sandstone and mudstones and rhyolitic rocks, with abundant fragments of I. uwajimensis. They are high-density turbidite beds, exhibiting the $\mathrm{S}_{1-2}$ divisions of Lowe (1982). The KY-6 
unit (the Tsukimi Sandstone Member) is $20 \mathrm{~m}$ thick and exposed in the eastern Mikasa area. This unit consists mostly of volcaniclastic sandstones with very thin interbedding of dark grey mudstones. The sandstone beds range from $0.2-2 \mathrm{~m}$ thick, and display the $\mathrm{S}_{1}-\mathrm{T}_{\mathrm{b}-\mathrm{e}}$ divisions of Lowe (1982) (Fig. $\left.7 \mathrm{~N}\right)$.

In the Tomamae area, this formation consists of two coarsening-upwards sequence. Both sequences begin with strongly bioturbated mudstone, grade into bioturbated muddy sandstone, and end up as medium- to coarse-grained, cross-laminated sandstone (Fig. 7O). The lower coarsening-upward sequence incorporates the volcaniclastic marker unit of the KY-5 in the lower part and the KY-6 at the top, respectively.

Thickness. Approximately $1950 \mathrm{~m}$ in the Mikasa area, 1750 to $2250 \mathrm{~m}$ in the Tomamae area.

Fossils and age. This formation yields abundant, well-preserved macrofossils from calcareous concretions in both the Tomamae and Mikasa areas (e.g., Futakami, 1986; Maeda, 1986; Wani, 2001; Moriya et al., 2003). Several regional biozones as $I$. uwajimensis-I. mihoensis, I. amakusensis, and I. japonicus inoceramid zones were proposed in the Tomamae area (Toshimitsu and Maiya, 1986). Microfossils are abundant throughout the study areas. Although Tethyan planktonic foraminifers are sporadic, the four mid-latitude zones, from the Marginotruncana pseudolinneiana to Globotruncana arca pf zones, can be identified in this formation. 
The geological age is assigned as Coniacian-Campanian (Nishi et al., 2003; Moriya et al., 2001 ; Fig. 8).

Depositional environment. The mudstone in the northern Tomamae area contains abundant benthic foraminifers, e.g. Gavelinella, Gyroidinoides, Hoeglundina, Oolina, Silicosigmoilina. The palaeodepth of this assemblage is considered to be outer shelf (Sliter and Baker, 1972). The cross-stratified sandstone situated towards the top of each succession (e.g., KY-6) in the northern Tomamae area is inferred to have been deposited in inner shelf to lower shoreface environments (Toshimitsu, 1985; Wani, 2003).

3.9. Hakobuchi Formation (new)

Definition. This formation is defined by the predominance of $\mathrm{HCS}$ and TCS sandstones and conglomerates, and corresponds to the Hakobuchi Group of Matsumoto (1942).

Type-section. Downstream of the Shuparo River (dam-site of Lake Shuparo) in the Oyubari area (Figs. 4, 6: section 15).

Stratigraphic relationships. This formation conformably overlies the Kashima Formation in the Oyubari area and the Haborogawa Formation in the north-eastern 
Mikasa and Tomamae areas. However, the unconformable relationship between the Haborogawa and Hakobuchi formations is recognized in the north-western limb of the Sorachi Anticline, north-western Mikasa area. The Hakobuchi Formation is overlain by a disconformity, or an angular unconformity, and is covered by deposits younger than the Palaeocene, such as the middle-upper Eocene Ishikari Group, containing coal measures, or the upper Eocene-lower Oligocene offshore-marine Poronai Group.

Lithology. As the deposits of the Hakobuchi Formation form complicated stacking patterns of the third- and fourth-order depositional sequences (DSs), lithology varies depending on areas and horizons, as in the Mikasa Formation (Ando, 2003). The number of sequences differs between sections, but the maximum reaches over 15 , including third-and fourth-order DSs. They mainly consist of coarsening-upwards facies successions (CUS), a few tens to $100 \mathrm{~m}$ thick, of bioturbated sandy mudstone to HCS/TCS sandstone (Fig. 7P). Often, there is an associated thin fining-upwards marine succession (FUS), less than several metres thick, below the CUS. Fluvial conglomerate, sandstone, mudstone and sometimes coaly beds are intercalated in the basal part of DSs. Thick marine conglomerate and fluvial-channel conglomerate are subordinately developed at several horizons. Felsic tuffs are interbedded at a few horizons, and thicken in the northern Mikasa and northern Tomamae areas, where the beds attain 30 and $80 \mathrm{~m}$ thick, respectively. Compared with the Mikasa Formation, the Hakobuchi Formation is characterized by a smaller amount of offshore mudstone 
and a larger amount of conglomerate and tuff.

Thickness and distribution. The thickness is variable, ranging from several tens to $450 \mathrm{~m}$ thick in the Mikasa and Oyubari areas (Ando, 1997). The formation is $250 \mathrm{~m}$ thick in the northernmost part of the Tomamae area.

Fossils and age. Although a few macrofossils, such as Sphenoceramus schmidti (Michael), S. hetonaianus (Matsumoto), and Inoceramus shikotanensis Nagao and Matsumoto, occur in this formation (Ando, 1997; Ando et al., 2001), there are no age-diagnostic species. The planktonic foraminifers Globotruncana rugosa (Marie) and Subbotina triloculinoides (Plummer) occur in the lower and upper parts of this formation, respectively (Yasuda, 1986). The former is assigned to the Campanian (Robaszynski et al., 1984), and the latter is of Palaeocene age (Yasuda, 1986). The Cretaceous/Tertiary boundary sequence has not been detected in the Hakobuchi Formation.

Depositional environment. Depending upon the stratigraphic position within the third- or fourth-order DSs, depositional environments change regularly and repetitively. They include shallow-marine environments, such as outer to inner shelf and shoreface, and subordinately estuarine, incised valley, and riverine gravelly/sandy river-channel, back-marsh and flood-plain. 


\section{Lateral change of depositional environments in the Yezo Basin}

The Yezo Group is lithologically characterized by an alternating sequence of turbidite-dominant and hemipelagic mudstone-dominant units (Fig. 2). The Aptian-Albian sequences are laterally similar in all study areas, comprising the laminated mudstone Soashibetsugawa Formation, the turbiditic Shuparogawa and Maruyama formations, and the mudstone Hikagenosawa Formation, in ascending order. Sedimentary structures, lithological associations and sedimentary sequences show submarine fan systems with channel-fill structures. Scarce occurrences of macrofossils, and common occurrence of deep-sea trace fossils, suggest abyssal environments in the Aptian. Benthic foraminifers indicate the upper bathyal zone, about 300-600 $\mathrm{m}$ in depth, in the Albian.

The Cenomanian-lower Campanian rocks display a lateral variation of lithology, tending to north-westward coarsening and shallowing sequences (Fig. 2). The uppermost Albian-Turonian Mikasa Formation is typically composed of shallow-marine, including fluvial, estuarine and outer-shelf sediments, suggesting rapid uplift in the western margin of the Yezo Forearc Basin. The overlying Haborogawa Formation represents deeper facies than the Mikasa Formation in terms of sedimentary environment, as indicated by the occurrence of shoreface to outer shelf, and partly upper bathyal basin-plain deposits. On the other hand, the Cenomanian-Turonian Saku Formation and Coniacian-Campanian Kashima 
Formation exhibit submarine fan systems and basin-plain, respectively. Based on benthic foraminiferal assemblages, these formations were deposited in upper bathyal depths.

The neritic to non-marine Hakobuchi Formation, deposited during the Campanian-Early Maastrichtian and Late Palaeocene interval, completely covers the deep-sea sediments across the whole area from north to south. This formation indicates the final stage of dumping and uplift of the Yezo Forearc Basin.

\section{OAE horizons in the Yezo Group}

Laminated, organic-rich marine sediments, indicating six oceanic anoxic events (OAEs 1a-1d, 2 and the mid-Cenomanian Event, MCE) have been reported from mid-Cetaceous deep-sea cores and land sections in the European Basin, North and South Atlantic oceans, and equatorial mid-Pacific mountains and plateaus (e.g., Erbacher et al., 1996; Leckie et al., 2002; Coccioni and Galeotti, 2003). These sediments are visually-distinctive, so-called 'black shales', found as black to dark grey-coloured intercalations in white, pelagic limestones or grey-coloured marlstones. These black shale intervals commonly consist mainly of finely alternating layers of calcareous fossil-rich laminae and clay/organic matter (Arthur and Sageman, 1994).

However, terrigenous, siliciclastic sequences exposed in the North Pacific regions, such as the Yezo Group in Japan, are generally composed of dark grey-coloured mudstones and palegrey sandstones. Darkgrey, 
monotonously-coloured deposits throughout the successions prevent visual recognition of OAE levels in background sediments in certain outcrops. In the Yezo Group, the average total organic carbon (TOC) content is about $0.5-1.2$ wt\% (Hasegawa and Saito, 1993), higher than those in the Tethyan and Atlantic carbonate rocks and marlstones (usually TOC is less than $0.5 \mathrm{wt} \%$ ). The origin of the organic matter is mostly from terrestrial plants throughout the sequences, suggesting that organic fragments (origin of the TOC) were transported from the westward Asian continental margin. Therefore, as the TOC of the Yezo Group is not a useful indicator of anoxic environments, the biostratigraphy and chemostratigraphy are both very important in identifying OAE horizons in this sequence. Several chemostratigraphic studies, using organic carbon isotopes from the Saku Formation, have reported a positive $\delta^{13} \mathrm{C}_{\mathrm{org}}$ excursion record, related to the global burial event of marine organic matter around the Cenomanian/Turonian boundary (OAE2; Hasegawa and Saito, 1993; Hasegawa, 1995, 1997; Hasegawa and Hatsugai, 2000). Moreover, another positive $\delta^{13} \mathrm{C}_{\mathrm{org}}$ excursion (about $3.6 \%$ ) was observed in the Soashibetsugawa Formation of the northern part of the Oyubari area (OAE1a; Ando et al., 2002, 2003). Here, we summarize the published biostratigraphic and chemostratigraphic results of the study areas, using the new stratigraphic classification presented in this paper (Fig. 8), and identify and describe the OAE horizons in the sequence.

\subsection{OAE1 a horizon}


The late Early Aptian OAE 1a, spanning about 1 myr (119.5-120.5 Ma; Larson and Erba,1999), named as the Niveau Goguel in the Vocontian Basin of France, Livello Selli in Italy and Fischschiefer in Germany, is a global, organic-carbon burial-event. This OAE occurred within the basal part of the Leupoldina cabri pf zone (Premoli-Silva et al., 1999). There was a microfossil (planktonic foraminifers and radiolarians) diversity decrease, and nannoconid (calcareous nannoplankton) species disappeared around the OAE1a event (Erba, 1994; Premoli-Silva et al., 1999). The sharp negative $\delta^{13} \mathrm{C}_{\text {carbonate }}$ excursion $(0.5-3 \%)$, and the following abrupt, prolonged positive one $(>2 \%)$, are recorded in this event (Menegatti et al., 1998).

In the Yezo Group, a pair of negative and positive $\delta^{13} \mathrm{C}_{\mathrm{org}}$ excursions have been found in the Soashibetsugawa Formation of the Sorachi Group in the Oyubari area (Ando et al., 2002, 2003). This formation has been redefined as the Soashibetsugawa Formation of the Yezo Group, as described above. Because the paired excursion spikes occur near the first appearance datum (FAD) of Leupoldina cabri, this positive excursion is correlative with the OAEla event (Fig. 8). The OAE 1 a interval in the study area is very thick, about $110 \mathrm{~m}$ (Fig. 6: section 11), compared with 1-5 $\mathrm{m}$ in the Italian and Swiss sections (Menegatti et al., 1998). The extraordinarily thick interval in the Yezo Group resulted from a huge terrestrial influx from the active Asian continental margin. Mudstone in this interval is characterized by rare bioturbation and fine lamination, with rare or barren benthic macro- and microfaunas. 


\subsection{OAE1b horizon}

OAE1b was a long-lived event, extending from the Ticinella bejaouaensis to Hedbergella planispira pf zones (114.5-108.21 Ma, about $6.3 \mathrm{myr}$; Hardenbole et al., 1998). This event is represented by several black shales: (1) the uppermost Aptian Niveau Jacob in the Vocontian Basin and Livello '113' in central Italy, and (2) the lower Albian Niveau Kilian, Paquier and Leenhardt in the Vocontian Basin, and Livellos Monte Nerone and Urbino in the Apennines of central Italy.

In the Yezo Group, an interval spanning the $T$. bejaouaensis to $H$. planispira pf zones was not detected, because the interval is placed within the olistostrome bed (Fig. 8). OAE1b, conseqently, is missing owing to erosion or hiatus by a tectonic event in the study area.

\subsection{OAE1c horizon}

Black shales representing the OAE1c event are characterized by abundant terrigenous organic matter in the lower Upper Albian Biticinella breggiensis pf zone in central Italy (Amadeus Level) (Erbacher et al., 1996). The $\delta^{13} \mathrm{C}_{\text {carbonate }}$ excursions within the $B$. breggiensis pf zone are not distinct in the Italian section (Erbacher et al., 1996), whereas a prominent negative excursion of $\delta^{13} \mathrm{C}_{\mathrm{org}}(1.5 \%)$ has been identified in the Santa Rosa section, Mexico (Bralower et al., 1999).

In the Yezo Group, the B. breggiensis pf zone spans the uppermost part of the Shuparogawa Formation to the basal part of the Hikagenosawa Formation (Fig. 
8), and is $300 \mathrm{~m}$ thick. A negative $\delta^{13} \mathrm{C}_{\mathrm{org}}$ excursion of about $1 \%$ is marked in the top the Shuparogawa Formation (Hirano and Fukuju, 1997), and followed by a radiolarian high productivity event in the Maruyama Formation (Fig. 8). This excursion interval could be correlatable with the OAE1c horizon of Leckie et al. $(2002)$.

Fig. 8 near here

\subsection{OAE1d horizon}

The uppermost Albian black shales (OAE1d, Breistroffer Level) occur from the upper part of the Rotalipora appenninica pf zone, as well as from the Stoliczkaia dispar ammonite zone, in Tethyan-Atlantic regions (Gale et al., 1996; Wilson and Norris, 2001). Broad positive excursions of $\delta^{13} \mathrm{C}_{\mathrm{carb}}$ ate within this interval suggest globally-significant organic-carbon burial (Erbacher et al., 1996; Gale et al., 1996; Nederbragt et al., 2001; Wilson and Norris, 2001). The OAE1d horizon in the equatorial Atlantic area is marked by collapse of upper water-column stratification due to intensified winter mixing and reduced summer stratification (Wilson and Norris, 2001). Biological records indicate that this OAE event damaged planktonic foraminifer and radiolarian populations, as well as the carbonate platform (Erbacher et al., 1996; Nederbragt et a1., 2001).

In the Yezo Group, the $R$. appeninnica pf zone, is correlatable with the lower middle part of the Hikagenosawa Formation (Fig. 8). Although the base of the R. appeninnica pf zone is indefinite because of a thick interval of rare to barren 
planktonic foraminifers, mudstones in the lower part of this formation contain the upper Albian ammonoids Mortoniceras rostratum and Mariella bergeri (Kawabe et a1., 2003; Fig. 8). These ammonoids are index species of the upper Albian Stoliczkaia dispar ammonite zone, as well as the R. appeninnica pf zone, in Tethyan biozonations. A broad, positive excursion of the $\delta^{13} \mathrm{C}_{\mathrm{org}}$, which is similar to the $\delta^{13} \mathrm{C}_{\mathrm{carbonate}}$ curve of OAE1d in the Tethyan-Atlantic region, is observed in the lower part of the Hikagenosawa Formation, just below the Kanajiri Sandstone Member (KY-3) of the Yezo Group (Hirano and Fukuju, 1997; Fig. 8). This horizon is located within the upper part of the Stoliczkaia dispar ammonite chronozone (Kawabe et al., 2003). Hence, we concluded that this excursion level is correlatable with OAE1d.

The rocks correlated to the OAE1d interval are weakly-laminated and pyrite-rich mudstones. Planktonic foraminifers are very rare to absent, whereas spumellarian radiolarians suddenly increased in abundance. Agglutinated benthic foraminifers are common, with assemblages of Bathysiphon, Glomospira and Haplophragmoides, with rare Gyroidinoides and Lenticulina. The dominance of agglutinated forms might reflect relatively dysoxic conditions, as well as the Cenomanian/Turonian boundary (Kaiho and Hasegawa, 1994). Although a dissolution effect on calcareous species cannot be ruled out, our results suggest that dysoxic conditions developed and a radiolarian high productivity event took place during the OAE1d in the north-west Pacific.

\subsection{The mid-Cenomanian Event horizon}


The mid-Cenomanian Event (MCE) is a major turnover of foraminifers and radiolarians associated with a $0.7 \%$ positive shift in $\delta^{13} \mathrm{C}_{\mathrm{carbonate}}$ and a positive shift in the Sr/Ca ratio (Coccioni and Galeotti, 2003). The organic-rich layers corresponding to this event have been found in central Italy, the Vocontian Basin (Coccioni and Galeotti, 2003), and the North Atlantic (Deep Sea Drilling Project Sites 367, 386 and 398; Cool, 1982; Arthur and Dean, 1986; Summerhayes, 1987). In central Italy, this event is associated with upper Cenomanian organic-rich layers up to the Cenomanian/Turonian boundary. The MCE level shows a global positive excursion in carbon isotope records, correlatable within the middle part of the Dicarinella algeriana pf subzone of the Rotalipora cushmani pf zone. Above this event, radiolarian and benthic foraminifers decrease in diversity in central Italy (Erbacher et al., 1996; Damesté and Köster, 1998; Coccioni and Galeotti, 2003).

Hasegawa (1997) proved a sudden positive excursion of $\delta^{13} \mathrm{C}_{\mathrm{org}}$ (about $1.2 \%$ ) within KS19a (= the D. algeriana pf subzone) in the Hakkin-zawa River (Shirokin River in Hasegawa, 1997) section of the Oyubari area. This positive peak is probably correlatable with the MCE horizon in central Italy. Therefore, the horizon is placed at the top of the Hikagenosawa Formation of our lithostratigraphic division. Benthic foraminiferal assemblages show a stepwise extinction, marked by $43 \%$ reduction of calcareous species during the 3 myr after the MCE event in the southern Oyubari area (Kaiho and Hasegawa, 1994; Fig. 8). Radiolarian abundances decrease during the same interval (Taketani, 1982). 
OAE2 (the Bonarelli Event) was the largest environmental and biotic disturbance during the mid-Cretaceous interval. Major phenomena include maximum mixed-layer temperatures (about 33-34 ${ }^{\circ} \mathrm{C}$; Wilson et al., 2002), an abrupt drop in ${ }^{87} \mathrm{Sr} /{ }^{86} \mathrm{Sr}$ isotopic values (Bralower et al., 1997), increased volcanic deposits and intensive hydrothermal activity (Sinton and Duncan, 1997). This event is marked by a positive excursion of $\delta^{13} \mathrm{C}_{\mathrm{c} a \mathrm{rbonate}}(>2 \% \mathrm{~m})$ within the Whiteinella archaeocretacea pf zone, close to the Cenomanian/Turonian ( $\mathrm{C} / \mathrm{T})$ boundary, and is considered to be related to increased productivity and global expansion of the oxygen minimum zone (e.g., Damesté and Köster, 1998; Premoli-Silva et al., 1999). A significant turnover of radiolarians, calcareous nannofossils, and deep-dwelling planktonic foraminifers occurred, with a high extinction rate (26\% of all genera) of benthic foraminifers (Erbacher et al., 1996; Erbacher and Thurow, 1997; Premoli-Silva et al., 1999).

The C/T boundary, based on macro- and microfossil biostratigraphy, is placed at the base of the Hakkin Muddy Sandstone Member of the Saku Formation in the Oyubari and Tomamae areas (Figs. 4, 6: sections 10, 13, and 14). A positive $\delta^{13} \mathrm{C}_{\mathrm{org}}$ excursion of about $2.5 \%$ is recorded at this boundary, indicating OAE2 (e.g., Hasegawa and Saito, 1993). Investigation of benthic foraminiferal assemblages in the Oyubari area demonstrates that the two lowest oxygen conditions developed during 0.15 myr before the $\mathrm{C} / \mathrm{T}$ boundary and 1.5 myr after (Kaiho and Hasegawa, 1994). Radiolarians become abundant just above the C/T boundary (e.g., Hasegawa, 1997: Fig. 8). 


\section{Conclusions}

Our study of the Yezo Group, a thick, forearc basin-fill sequence, distributed across Hokkaido, Japan, serves as an important record of tectonic, faunal and environmental change on the north-west Pacific margin during the Cretaceous Period. The litho- and biostratigraphic summaries of the sequence were previously little known, and various lithostratigraphic divisions had been proposed. Based on our wide areal mapping of the sequences, as well as analyses of litho- and biofacies, we have here proposed a new lithostratigraphic scheme for the sequence.

The Aptian-Albian sequences (the Soashibetsugawa, Shuparogawa, Maruyama and lower Hikagenosawa formations) of the group were formed on a continental slope with a lower-upper bathyal palaeodepth in all sections. The Cenomanian to lower Campanian sequences exhibit lateral variations of sedimentary environment in the study areas. Generally, the sequences exposed in the Mikasa and Tomamae areas show shallower facies of shelf to non-marine environment (the Mikasa and Haborogawa formations), while those in the Oyubari area represent a continental slope environments (the upper Hikagenosawa, Saku, Kashima formations). Above the lower Campanian, the neritic to non-marine facies of the Hakobuchi Formation were deposited in all areas.

The sequence does not contain intercalated black shales, as seen in the Tethyan and Atlantic regions, because of rapid sedimentation and a constant voluminous influx of terrigenous detritus. However, the integration of the bio- and 
chemostratigraphic results of the study areas, using our new stratigraphic scheme, reveals the horizons of OAE 1a, 1c, 1d, MCE and 2 in the Yezo Group. OAE1a, 1c, 1d and 2 horizons are characterized by a lack of calcareous foraminifers, instead, they are closely accompanied by a radiolarian high productivity event. On the other hand, MCE horizon corresponds to the onset of decrease in radiolarian abundance and stepwise extinction of calcareous benthic foraminifers.

\section{Acknowledgments}

We express sincere gratitude to Y. Takayanagi, T. Saito (Tohoku University), H. Hirano (Waseda University), S. Sano (Fukui Prefectural Dinosaur Museum), T. Tomosugi (Kyushu University), and K. Kurihara (Mikasa City Museum) for helpful suggestions, and also to K. Kobayashi, K. Hasegawa, S. Matsuda, K. Matsuda, N. Watanabe, K. Komoto (Mikasa City) for supports during our fieldwork. We thank T. Hatsugai, A. Ennyu, S. Egawa, F. Suzuki, A, Ando and T. Sakai for provision of unpublished data. This study was supported financially by the JSPS Research Fellows Scheme (No. 09898 to Takashima, No. 06365 to Wani, and No. 07622 to Moriya), Grants-in-Aid from JSPS (No. 14740302 to Kawabe, No. 10640446 to Ando, and Nos. 13354006 and 15340176 to Nishi), and in part by a 21 st Century Center of Excellence (COE) Program on "Neo-Science of Natural History" at Hokkaido University. 


\section{References}

Ando, A., Kakegawa, T., Takashima, R., Saito, T., 2002. New perspective on Aptian carbon isotope stratigraphy: data from $\delta^{13} \mathrm{C}$ records of terrestrial organic matter. Geology 30, 227-230.

Ando, A., Kakegawa, T., Takashima, R., Saito, T., 2003. Stratigraphic carbon isotope fluctuations of detrital woody materials during the Aptian Stage in Hokkaido, Japan: comprehensive $\delta^{13} \mathrm{C}$ data from four sections of the Ashibetsu area. J. Asian Earth Sci. 21,835-847.

Ando, H., 1990a. Shallow-marine sedimentary facies distribution and progradational sequences of the Mikasa Formation, Middle Yezo Group (Upper Cretaceous). J. Geol. Soc. Japan 96, 453-469. [In Japanese, English abstract]

Ando, H., 1990b. Stratigraphy and shallow marine sedimentary facies of the Mikasa Formation, Middle Yezo Group (Upper Cretaceous). J. Geol. Soc. Japan 96, 279-295. [In Japanese, English abstract]

Ando, H., 1997. Apparent stacking patterns of depositional sequences in the Upper Cretaceous shallow-marine to fluvial successions, northeast Japan. Mem. Geol. Soc. Japan 48, 43-59.

Ando, H., 2003. Stratigraphic correlation of Upper Cretaceous to Paleocene forearc basin sediments in northeast Japan: cyclic sedimentation and basin evolution. J. Asian Earth Sci. 21,921-935.

Ando, H., Tomosugi, T., Kanakubo, T., 2001. Upper Cretaceous to Paleocene Hakobuchi Group, Nakatonbetsu area, northern Hokkaido-lithostratigraphy and 
megafossil biostratigraphy. J. Geol. Soc. Japan 107, 142-162.

Arthur, M.A., Dean, W.E., 1986. Cretaceous paleoceanography. In: Tucholke, B.E., Vogt, P.R. (Eds). Decade of North American Geology, Western North Atlantic Basin Synthesis Volume. Geological Society of America, 617-630.

Arthur, M.A., Sageman, B.B., 1994. Marine black shales: depositional mechanisms and environments of ancient deposits. Annu. Rev. Earth Planet. Sci. 22, 499-551.

Bralower, T.J., Arthur, M.A., Leckie, R.M., Sliter, W.V., Allard, D.J., Schlanger, S.O., 1994. Timing and paleoceanography of oceanic dysoxia/anoxia in the Late Barremian to early Aptian (Early Cretaceous). Palaios 9, 335-369.

Bralower, T.J., Cobabe, E., Clement, B., Sliter, W.V., Osburn, C.L., Longoria, J., 1999. The record of global change in mid-Cretaceous (Barremian-Albian) sections from the Sierra Madre, northeastern Mexico. J. Foram. Res. 4, 418-437.

Bralower, T.J., Fullagar, P.D., Paull, C.K., Dwyer, G.S., Leckie, R.M., 1997. Mid-Cretaceous strontium-isotope stratigraphy of deep-sea sections. Geol. Soc. Am. Bull. 109, 1421-1442.

Bralower, T.J., Sliter, W.V., Arthur, M.A., Leckie, R.M., Allard, D., Schlanger, S.O., 1993. Dysoxic/anoxic episodes in the Aptian-Albian (Early Cretaceous). In: Pringle, M.S., Sager, W.W., Sliter, W., Stein, S. (Eds). The Mesozoic Pacific: geology, tectonics, and volcanism. AGU, 5-37.

Coccioni, R., Galeotti, S., 2003. The mid-Cenomanian Event: prelude to OAE2. Palaeogeogr. Palaeoclimato1. Palaeoecol. 190, 427-440.

Cool, T.E., 1982. Sedimentological evidence concerning the paleoceanography of 
the Cretaceous western north Atlantic Ocean. Palaeogeogr. Palaeoclimatol. Palaeoecol. 39, 1-35.

Damesté, J.S.S., Köster, J., 1998. A euxinic southern North Atlantic Ocean during the Cenomanian/Turonian oceanic anoxic event. Earth Planet. Sci. Lett. 158, $165-173$.

Erba, E., 1994. Nannofossils and superplumes: The early Aptian "nannoconid crisis". Paleoceanography 9, 485-501.

Erbacher, J., Thurow, J., 1997. Influence of oceanic anoxic events on the evolution of mid-Cretaceous radiolaria in the North Atlantic and western Tethys. Mar. Micropaleonto1. 30,139-158.

Erbacher, J., Thurow, J., Littke, R., 1996. Evolution patterns of radiolaria and organic matter variations: a new approach to identify sea-level changes in mid-Cretaceous pelagic environments. Geology 24, 499-502.

Futakami, M., 1982. Cretaceous stratigraphy and ammonite assemblages of the Hatonosu area, central Hokkaido. J. Geol. Soc. Japan 88, 101-120. [In Japanese, English abstract]

Futakami, M., 1986. Stratigraphy and paleontology of the Cretaceous in the Ishikari province, central Hokkaido. Part 1. Stratigraphy of the Cretaceous in the southern areas. Bu11. Natn. Sci. Mus., Tokyo, Ser. C, Geol. 12, 7-34.

Gale, A.S., Kennedy, W.J., Burnett, J.A., Caron, M., Kidd, B.E., 1996. The Late Albian to Early Cenomanian succession at Mont Risou near Rosans (Drôme, SE France): an integrated study (ammonites, inoceramids, planktonic foraminifera, 
nannofossils, oxygen and carbon isotops). Cret. Res. 17, 515-606.

Girard, M., Jolivet, L., Nakagawa, M., Aguirre, L., Niida, K., 1991. Acidic volcanic products in Lower Cretaceous deposits of the Sorachi-Yezo Belt, Hokkaido, northeast Japan. J. Geol. Soc. Japan 97, 1-14.

Hardenbol, J., Thierry, J., Farley, M.B., Jaquin, T., de Graciansky, P.-C., Vail, P.R., 1998. Cretaceous chronostratigraphy. In: Graciansky, P.-C., Hardenbol, J., Jaquin, T., Vail, P. R. (Eds). Mesozoic and Cenozoic sequence chronostratigraphic framework of European basins. SEPM Spec. Pub. 60, 3-13. Hasegawa, T., 1995. Correlation of the Cenomanian/Turonian boundary between Japan and Western Interior of the United States. J. Geol. Soc. Japan 101, 2-12.

Hasegawa, T., 1997. Cenomanian-Turonian carbon isotope events recorded in terrestrial organic matter from northern Japan. Palaeogeogr. Palaeoclimatol. Palaeoecol. 130, 251-273.

Hasegawa, T., Hatsugai, T., 2000. Carbon-isotope stratigraphy and its chronostratigraphic significance for the Cretaceous Yezo Group, Kotanbetsu area, Hokkaido, Japan. Paleontol. Res. 4, 95-106.

Hasegawa, T., Saito, T., 1993. Global synchroneity of a positive carbon isotope excursion at the Cenomanian/Turonian boundary: validation by calcareous microfossil biostratigraphy of the Yezo Group, Hokkaido, Japan. The Island Arc $3,181-191$.

Hashimoto, W., 1953. Explanatory text of the geological map of Japan 'Yamabe' (scale1:50000). Geological survey of Hokkaido, 82 pp. [In Japanese, English 
summary]

Hirano, H., 1995. Correlation of the Cenomanian/Turonian boundary between Japan and Western Interior of the United States in relation with oceanic anoxic events. J. Geol. Soc. Japan 101,13-18.

Hirano, H., Fukuju, T., 1997. Lower Cretaceous oceanic anoxic event in the Lower Yezo Group, Hokkaido, Japan. J. Geol. Soc. Philippines 52, 173-182.

Hoshi, H., Takashima, R., 1999. Paleomagnetic analysis for some volcanic rocks of the Sorachi Group in the Furano area, central Hokkaido, Japan. Bull. Mikasa City Mus., Nat. Sci., no. 3, 23-30. [In Japanese, English abstract]

Ishizuka, H., 1981. Geochemistry of the Horokanai Ophiolite in the Kamuikotan Tectonic Belt, Hokkaido, Japan. J. Geol. Soc. Japan 87, 17-34.

Kaiho, K., Fujiwara, O., Motoyama, I., 1993. Mid-Cretaceous faunal turnover of intermediate-water benthic foraminifera in the northwestern Pacific Ocean margin. Mar. Micropaleontol. 23, 13-49.

Kaiho, K., Hasegawa, T., 1994. End-Cenomanian benthic foraminiferal extinctions and oceanic dysoxic events in the northwestern Pacific Ocean. Palaeogeogr. Palaeoclimatol. Palaeoecol. 111, 29-43.

Kawabe, F., 2000. Cretaceous stratigraphy in the Oyubari area, central Hokkaido, Japan. Bull. Natn. Sci. Mus., Tokyo, Ser. C, Geol. 26, 9-56.

Kawabe, F., 2003. Relationship between mid-Cretaceous (upper Albian to Cenomanian) ammonoid facies and lithofacies in the Yezo forearc basin, Hokkaido, Japan. Cret. Res. 24, 751-763. 
Kawabe, F., Hirano, H., Takagi, K., 1996. Biostratigraphy of the Cretaceous System in the northern Oyubari area, Hokkaido. J. Geol. Soc. Japan 102, 440-459. [In Japanese, English abstract]

Kawabe, F., Takashima, R., Wani, R., Nishi, H., Moriya, K., 2003. Upper Albian to Lower Cenomanian biostratigraphy in the Oyubari area, Hokkaido, Japan: toward a Cretaceous biochronology for the North Pacific. Acta Geol. Polonica 53, 81-91.

Kiminami, K., Komatsu, M., Niida, K., Kito, N., 1986. Tectonic divisions and stratigraphy of the Mesozoic rocks of Hokkaido, Japan. Mon. Asso. Geol. Collab. Japan, 1-15. [In Japanese, English abstract]

Kito, N., Kiminami, K., Niida, K., Kanie, Y., Watanabe, T., Kawaguchi, M., 1986. The Sorachi Group and the Yezo Supergroup: late Mesozoic ophiolites and forearc sediments in the axial zone of Hokkaido. Mon. Asso. Geol. Collab. Japan, 81-96. [In Japanese, English abstract]

Kodama, K., Maeda, H., Shigeta, Y., Kase, T., Takeuchi, T., 2002. Integrated biostratigraphy and magnetostratigraphy of the Upper Cretaceous System along the River Naiba in southern Sakhalin, Russia. J. Geol. Soc. Japan 108, 366-384. [In Japanese, English abstract]

Larson, R.L., 1991a. Geological consequences of superplumes. Geology 19, 963-966.

Larson, R.L., 1991b. Latest pulse of Earth: evidence for a mid-Cretaceous superplume. Geology 19, 547-550.

Larson, R.L., Erba, E., 1999, Onset of the mid-Cretaceous greenhouse in the 
Barremian-Aptian: igneous events and the biological, sedimentary, and geochemical responses. Paleoceanography 14, 663-678.

Leckie, R.M., Bralower, T.J., Cashman, R., 2002. Oceanic anoxic events and plankton evolution: biotic response to tectonic forcing during the mid-Cretaceous. Paleoceanography 17, 1-29.

Lowe, D.R., 1982. Sediment gravity flows: II. Depositional models with special reference to the deposits of high-density turbidity currents. J. Sediment. Petrol. $52,279-297$.

Maeda, H., 1986. Stratigraphy and fossil molluscan fauna of the Upper Cretaceous System in the Bibai area, Hokkaido, north Japan. J. Geol. Soc. Japan 92, 135-153. [In Japanese, English abstract]

Matsumaru, K., 1971. Certain 1arger Foraminifera from Japan. J. Saitama Univ., Fac. Edu. 20, 149-159.

Matsumoto, T., 1942. Fundamentals in the Cretaceous stratigraphy of Japan, Part 1. Mem. Fac. Sci., Kyushu Univ., Ser. D, Geol. 1, 129-280.

Matsumoto, T., 1951. The Yezo Group and the Kwanmon Group. J. Geol. Soc. Japan 57, 95-98. [In Japanese, English abstract]

Matsumoto, T., 1977. Zonal correlation of the Upper Cretaceous in Japan. Palaeonto1. Soc. Japan, Spec. Pap. 21, 63-74.

Menegatti, A.P., Weissert, H., Brown, R.S., Tyson, R.V., Farrimond, P., Strasser, A., Caron, M., 1998. High-resolution $\delta^{13} \mathrm{C}$ stratigraphy through the early Aptian "Lievello Selli" of the Alpine Tethys. Paleoceanography 13,530-545. 
Moriya, K., Hirano, H., 2001. Cretaceous stratigraphy in the Chikubetsu area, Hokkaido. J. Geol. Soc. Japan 107, 199-214. [In Japanese, English abstract] Moriya, K., Nishi, H., Tanabe, K., 2001, Age calibration of megafossil biochronology based on Early Campanian planktonic foraminifera from Hokkaido Japan. Paleontol. Res. 5, 277-282.

Moriya, K., Nishi, H., Kawahata, H., Tanabe, K., Takayanagi, Y., 2003. Demersal habitat of Late Cretaceous ammonoids: evidence from oxygen isotopes for the Campanian (Late Cretaceous) northwestern Pacific thermal structure. Geology 31 , $167-170$.

Motoyama, I., Fujiwara, O., Kaiho, K., Murota, T., 1991. Lithostratigraphy and calcareous microfossil biochronology of the Cretaceous strata in the Oyubari area, Hokkaido, Japan. J. Geol. Soc. Japan 97, 507-527. [In Japanese, English abstract]

Nederbragt, A.J., Fiorentino, A., Klosowska, B., 2001. Quantitative analysis of calcareous microfossils across the Albian-Cenomanian boundary oceanic anoxic event at DSDP Site 547 (North Atlantic). Palaeogeogr. Palaeoclimatol. Palaeoecol. 166, 401-421.

Niida, K., 1992. Basalts and dolerites in the Sorachi-Yezo Belt, central Hokkaido, Japan. J. Fac. Sci., Hokkaido Univ., Ser. 4, 23, 301-319.

Nishi, H., Takashima, R., Hatsugai, T., Saito, T., Moriya, K., Ennyu, A., Sakai, T., 2003. Planktonic foraminiferal zonation in the Cretaceous Yezo Group, Central Hokkaido, Japan. J. Asian Earth Sci. 21,867-886. 
Nishida, T., Matsumoto, T., Kawashita, Y., Egashira, N., Aizawa, J., Ikkuji, Y., 1997. Biostratigraphy of the middle part of the Cretaceous Yezo Group in the Soeushinai area of Hokkaido-with special reference to the transitional part from Lower to Upper Cretaceous: supplement. J. Fac. Cul. Edu., Saga Univ. 1, 237-279.

Obata, I., Futakami, M., 1975, Cretaceous Stratigraphy of the Manji Area, Hokkaido. Bull. Natn. Sci. Mus., Ser. C, Geol., 1, 93-110. [In Japanese, English summary] Okada, H., 1974. Migration of ancient arc-trench systems. In: Dott, Jr. R. H., Shaver, R. H. (eds). Modern and ancient geosynclinal sedimentation. SEPM. Spec. Pub. $19,311-320$.

Okada, H., 1983. Collision orogenesis and sedimentation in Hokkaido, Japan. In: Hashimoto, M., Uyeda, S. (Eds). Accretion Tectonics in the Circum-Pacific Regions. Terra Scientific Publishing Company, Tokyo, 91-105.

Premoli-Silva, I., Erba, E., Salvini, G., Locatelli, C., Verga, D., 1999. Biotic changes in Cretaceous oceanic anoxic events of the Tethys. J. Foram. Res. 29, 352-370.

Robaszynski, F., Caron, M., Gonzales, J.M., Wonders, A., 1984. Atlas of Late Cretaceous planktonic foraminifera. Rev. Micropaleonto1.26, 145-305.

Saito, T., Ando, A., 2000. New findings of the planktonic foraminifer Leupoldina cabri (Sigal, 1952) from the Sorachi Group of Hokkaido, Japan and its bearing on the Cretaceous chronology of northwestern Pacific marine strata. Bull. Natn. Sci. Mus., Ser.C, Geol. 26, 183-191. 
Sano, S., 1995. Litho- and biofacies of Early Cretaceous rudist-bearing carbonate sediments in northeastern Japan. Sediment. Geol. 99, 179-189.

Sinton, C.W., Duncan, R.A., 1997. Potential links between ocean plateau volcanism and global ocean anoxia at the Cenomanian/Turonian boundary. Econ. Geol. 92, $836-842$.

Sliter, W.V., Baker, R.A., 1972, Cretaceous bathymetric distribution of benthic foraminifers. J. Foram. Res. 2, 167-183.

Sliter, W.V., 1989. Aptian anoxia in the Pacific Basin. Geology 17, 909-912.

Summerhayes, C.P., 1987. Organic-rich Cretaceous sediments from the North Atlantic. In: Brooks, J., Fleet, A.J. (Eds). Marine petroleum source rocks. Geol. Soc. London Spec. Pub 26,301-316.

Takashima, R., Nishi, H., Saito, T., Hasegawa, T., 1997. Geology and planktonic foraminiferal biostratigraphy of Cretaceous strata distributed along the Shuparo River, Hokkaido, Japan. J. Geol. Soc. Japan 103, 543-563. [In Japanese, English abstract]

Takashima, R., Yoshida, T., Nishi, H., 2001. Stratigraphy and sedimentary environment of the Sorachi and Yezo groups in the Yubari-Ashibetsu area, Hokkaido, Japan. J. Geol. Soc. Japan 107, 1-20. [In Japanese, English abstract]

Takashima, R., Nishi, H., Yoshida, T., 2002a. Geology, petrology and tectonic setting of the Late Jurassic ophiolite in Hokkaido, Japan. J. Asian Earth Sci. 21, 197-215.

Takashima, R., Nishi, H., Miyamoto, Y., Yoshida, T., 2002b. Geology and 
stratigraphy of the Sorachi and Yezo groups in the Tokyo University Forests in Hokkaido, Japan. Bull. Tokyo Univ. Forests 108, 57-76. [In Japanese, English abstract]

Taketani, Y., 1982. Cretaceous radiolarian biostratigraphy of the Urakawa and Obira areas, Hokkaido. Sci. Rep. Tohoku Univ., Sendai, Japan, Sec. Ser. (Geol.) 52, $1-76$.

Tanaka, K., 1963. A study on the Cretaceous sedimentation in Hokkaido, Japan. Rept. Geol. Surv. Japan 197. 1-122.

Tanaka, K., 1970. Sedimentation of the Cretaceous flysch sequence in the Ikushumbetsu area, Hokkaido, Japan. Rept. Geol. Surv. Japan 236, 1-107.

Toshimitsu, S., 1985. Biostratigraphy and depositional facies of the Cretaceous in the upper reaches of the Haboro River, Hokkaido. J. Geol. Soc. Japan 91, 599-618. [In Japanese, English abstract]

Toshimitsu, S., Maiya, S., 1986. Integrated inoceramid-foraminiferal biostratigraphy of the Upper Cretaceous of northwestern Hokkaido, Japan. Cret. Res. 7, 307-326.

Toshimitsu, S., Maiya, S., Inoue, Y., Takahashi, T., 1998. Integrated megafossil-foraminiferal biostratigraphy of the Santonian to lower Campanian (Upper Cretaceous) succession in northwestern Hokkaido, Japan. Cret. Res. 19, 69-85.

Ueda, H., Kawamura, M., Niida, K., 2000. Accretion and tectonic erosion processes revealed by the mode of occurrence and geochemistry of greenstones in the 
Cretaceous accretionary complexes of the Idonnappu Zone, southern central Hokkaido, Japan. The Island Arc 9, 237-257.

Wani, R., 2001. Reworked ammonoids and their taphonomic implications in the Upper Cretaceous of northwestern Hokkaido, Japan. Cret. Res. 22, 615-625. Wani, R., 2003. Taphofacies models for Upper Cretaceous ammonoids from the Kotanbetsu area, northwestern Hokkaido, Japan. Palaeogeogr. Palaeoclimatol. Palaeoecol. 199, 71-82.

Wani, R., Hirano, H., 2000. Upper Cretaceous biostratigraphy in the Kotanbetsu area, northwestern Hokkaido. J. Geol. Soc. Japan 106, 171-188. [In Japanese, English abstract]

Wilson, P.A., Norris, R.D., 2001. Warm tropical ocean surface and global anoxia during the mid-Cretaceous period. Nature 412, 425-429.

Wilson, P.A., Norris, R.D., Cooper, M.J., 2002. Testing the Cretaceous greenhouse hypothesis using glassy foraminiferal calcite from the core of the Turonian tropics on Demerara Rise. Geology 30, 607-610.

Yasuda, H., 1986. Cretaceous and Paleocene Foraminifera from northern Hokkaido, Japan. Sci. Rep. Tohoku Univ., Sendai, Japan. Sec. Ser. (Geol.) 57, 1-101. 


\section{Captions}

Fig. 1. Simple geological map showing the distribution of the Mesozoic formations of north-east Japan and southern Sakhalin. Dashed-lined frames show the study areas (Figs. 4, 5). The central region (Fig. 4) consists of the south-eastern Oyubari area and the north-western Mikasa area.

Fig. 2. Schematic diagram of the Yezo Group in the study areas. Note that the geological column shows rightward-deepening facies.

Fig. 3. Comparison of lithostratigraphic subdivisions proposed by several workers in the study areas.

Fig. 4. Geological map and structural profile section of the Oyubari and Mikasa areas, central Hokkaido Island region. The south-eastern Oyubari and north-western Mikasa areas are bounded by the Katsurazawa Thrust Fault. Although most areas in this map are based on our original data, the southern Mikasa area (the Manji and Hatonosu Domes) and northeastern Oyubari area (around the Mt. Yubaeyama) are modified from Tanaka, (1970), Obata and Futakami (1975), Futakami (1982), Hashimoto (1953), respectively.

Fig. 5. Geological map and structural profile section of the Tomamae area; see Fig. 4 for legend.

Fig. 6. Correlation of selected sections from the study areas. 1-5, Mikasa area. 1, Shikoro-zawa Valley; 2, Ponbetsu River; 3, Yonno-sawa Valley; 4, Ganseki-zawa Valley-Nanashi-zawa Valley; 5, Tsukimi-sawa Valley. 6-10, Tomamae area. 6, Sankebetsu River; 7, Nakafutamata River; 8, Shumarinai 
River; 9,. Sounnai River-Kotanbetsu River; 10, Gosen River-Kanajiri-zawa Valley-Akanosawa Valley. 11-17, Oyubari area. 11, Soashibetsu River; 12, Shuparo River; 13, Tengu-sawa Valley; 14, Hakkin-zawa Valley; 15, Oyubari dam, 16. Horokakuruki River, 17. Mayachi-zawa Valley. Each sections is cited in Figs. 4 and 5. Note that the precise thickness of the KY2 (section 11-13) and KY-5 could not be depicted because of scale problem. Precise thickness should refer to Table 1 .

Fig. 7. Photographs of the representative lithofacies of the Yezo Group. A, laminated mudstone with frequent intercalations of felsic tuff beds; Soashibetsugawa Formation, Soashibetsu River, northern Oyubari area. B, sandstone-dominant alternating beds of sandstone and mudstone; Shuparogawa Formation, Refureppu Sandstone Member, Soashibetsu River, northern Oyubari area. C, olistostrome containing large limestone blocks; Shuparogawa Formation, Kirigishiyama Olistostrome Member, Okusakaino-sawa Valley, central Oyubari area. D, alternating beds of sandstone and mudstone; Okusakainosawa Sandstone and Mudstone Member, Shuparo River, central Oyubari area. E, felsic tuffaceous sandstones; Maruyama Formation, Uenbetsu River, southern Tomamae area. F, weakly laminated mudstone; Hikagenosawa Formation, Tengu-sawa Valley, central Oyubari area. G, mudstone-dominant alternating beds of sandstone and mudstone; Hikagenosawa Formation, Kanajiri Sandstone Member, Shuparo River, central Oyubari area. H, alternating beds of sandstone and mudstone; Saku Formation, Shumarinai 
River, northern Tomamae area. I, greenish grey muddy sandstone with abundant Planolites; Saku Formation, KY-4, Hakkin-zawa Valley, southern Oyubari area. J, conglomerate bed with erosional base; Saku Formation, Shumarinai River, northern Tomamae area. K, sandstone with hummocky cross-stratification; Mikasa Formation, western Katsura-zawa Lake, southern Mikasa area. L, massive mudstone; Kashima Formation, Horokakuruki River, southern Oyubari area. M, Inoceramus uwajimensis shell bed; Kashima Formation, Okusamata-zawa Valley, central Oyubari area. N, felsic volcaniclastic sandstone; Haborogawa Formation, Tsukimi Sandstone Member, Ashibetsu River, eastern Mikasa area. O, coarsening upward sequences, from sandy mudstone to medium-grained sandstone; Haborogawa Formation, Nakanofutamata River, northern Tomamae area. P, sandstone with hummocky cross-stratification; Hakobuchi Formation, Hachigatsu-zawa Valley, eastern Mikasa area.

Fig. 8. Composite column of the Yezo Group, summarized lithology, macro-, microfossil and carbon isotope stratigraphy and microfossil biotic events. Note that five OAE horizons are identified within the Yezo Group.

Table 1. List of the widely traceable key units of the Yezo Group. 


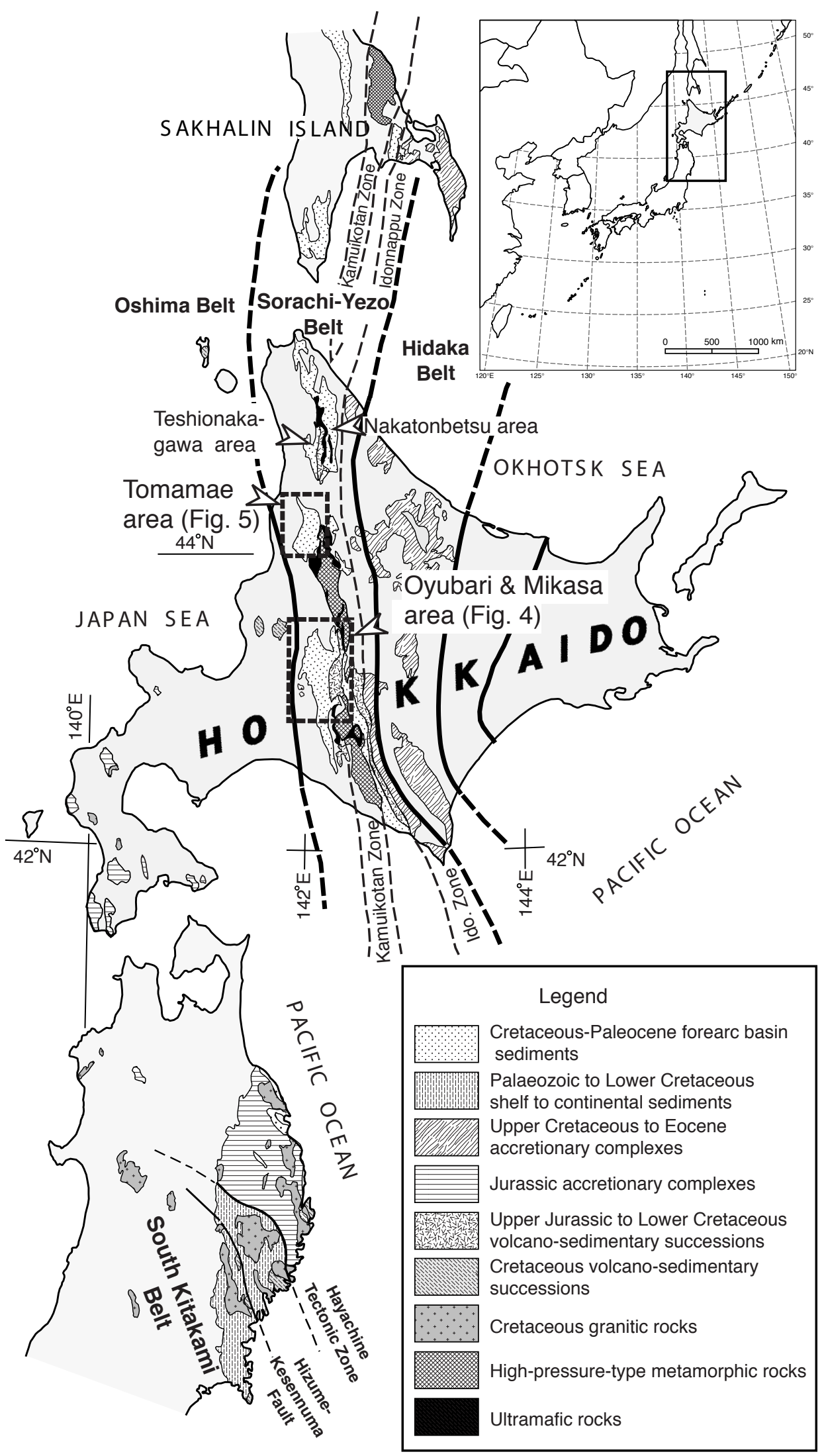

Figure 1, Takashima et al. 


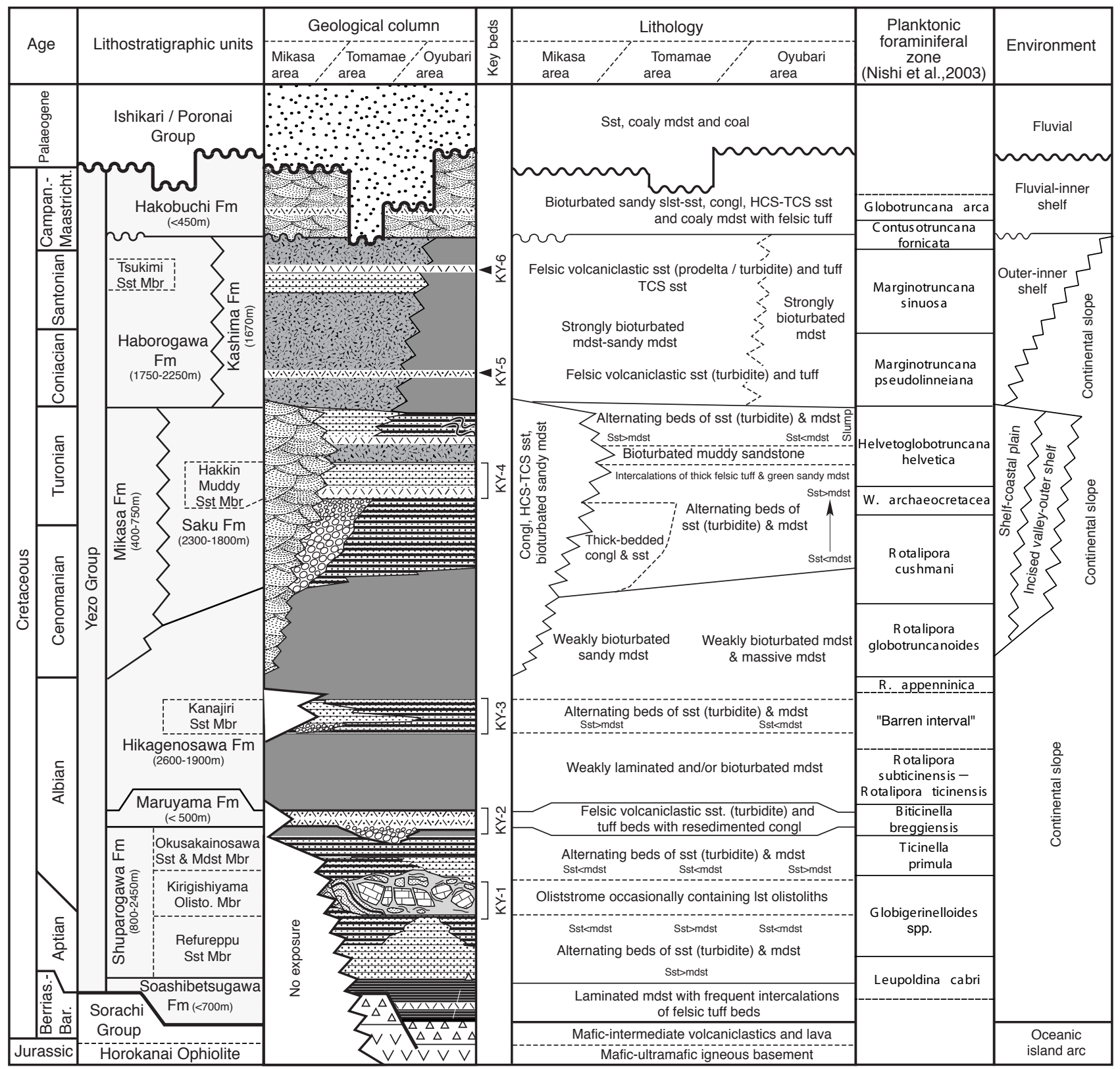




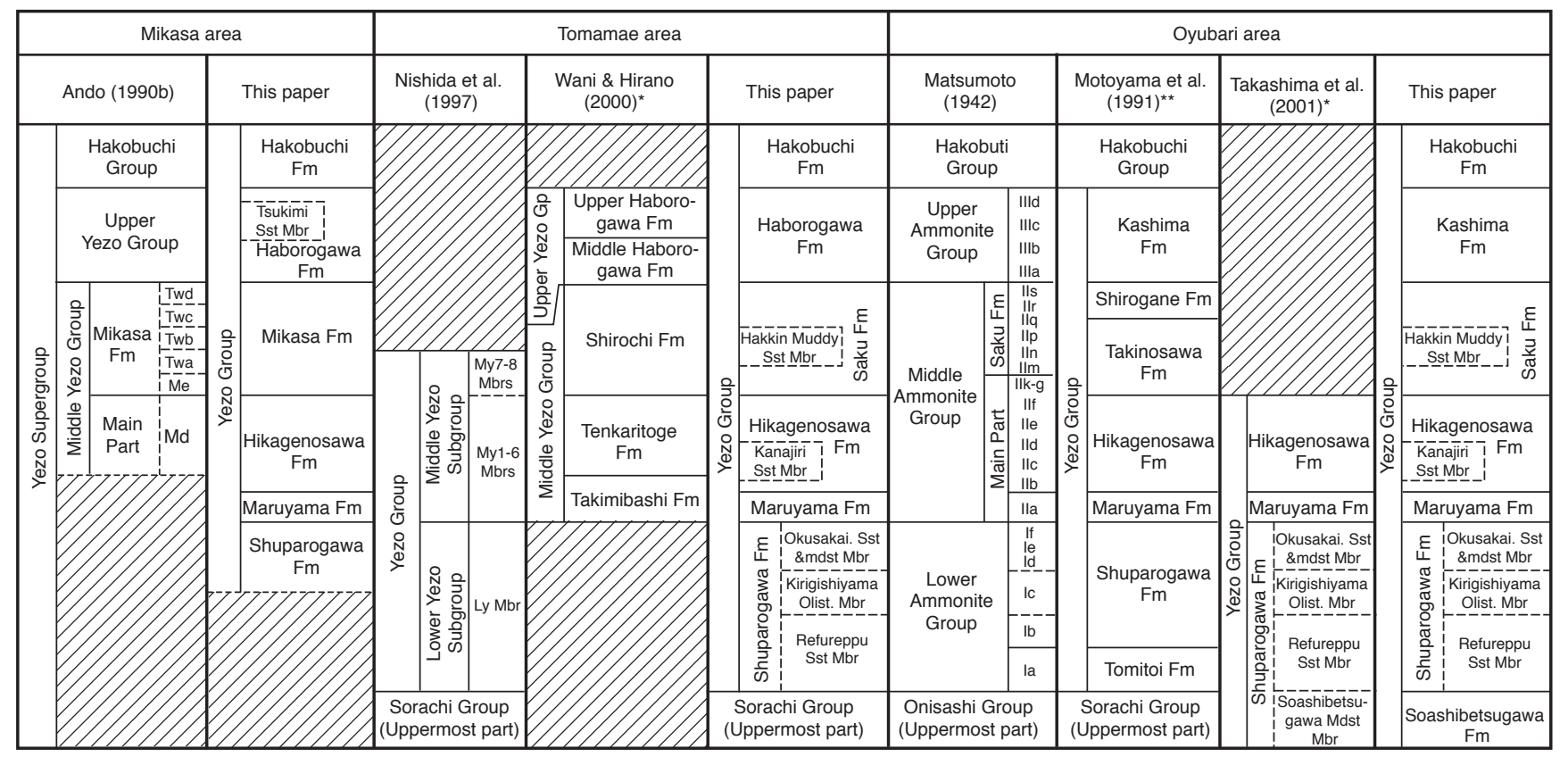

* Same definition is used in Nishi et al. (2003)

* * Same definition is used in Hasegawa \& Saito (1993), Kaiho et al. (1993), Kaiho \& Hasegawa (1994), Hasegawa (1995) and Hasegawa (1997)

Figure 3, Takashima et al. 


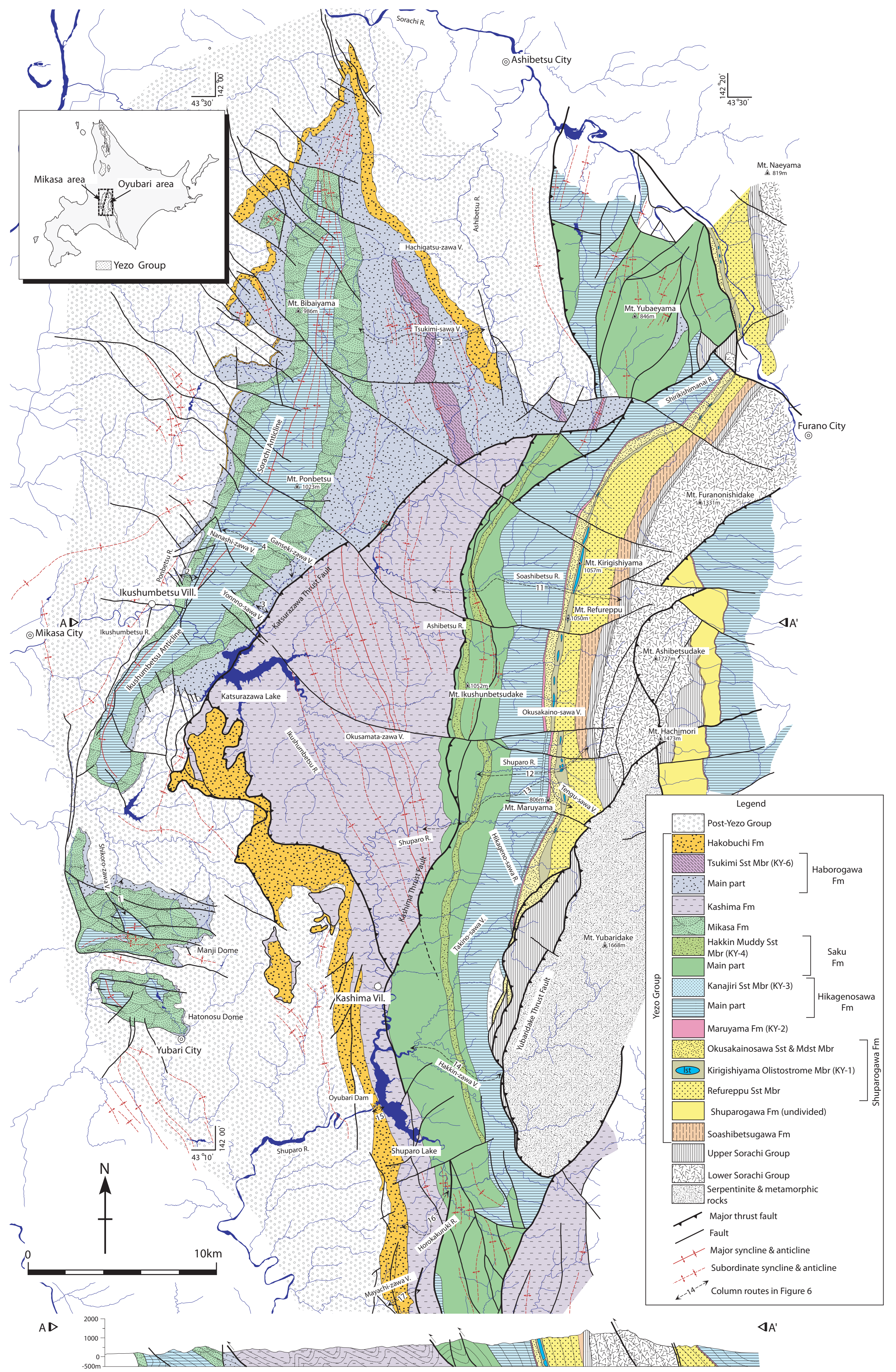

Figure 4, Takashima et al. 


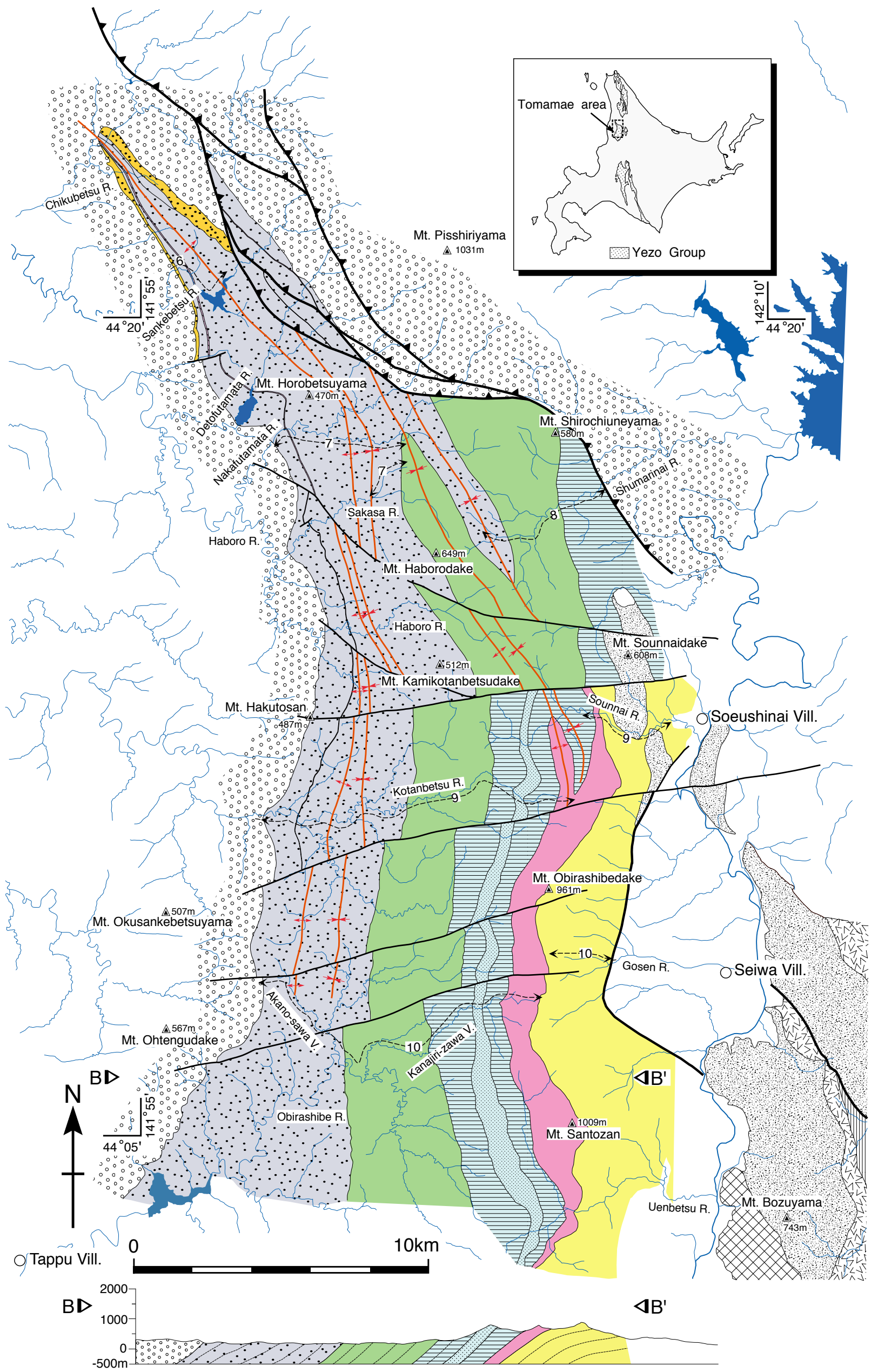

Figure 5, Takashima et al. 

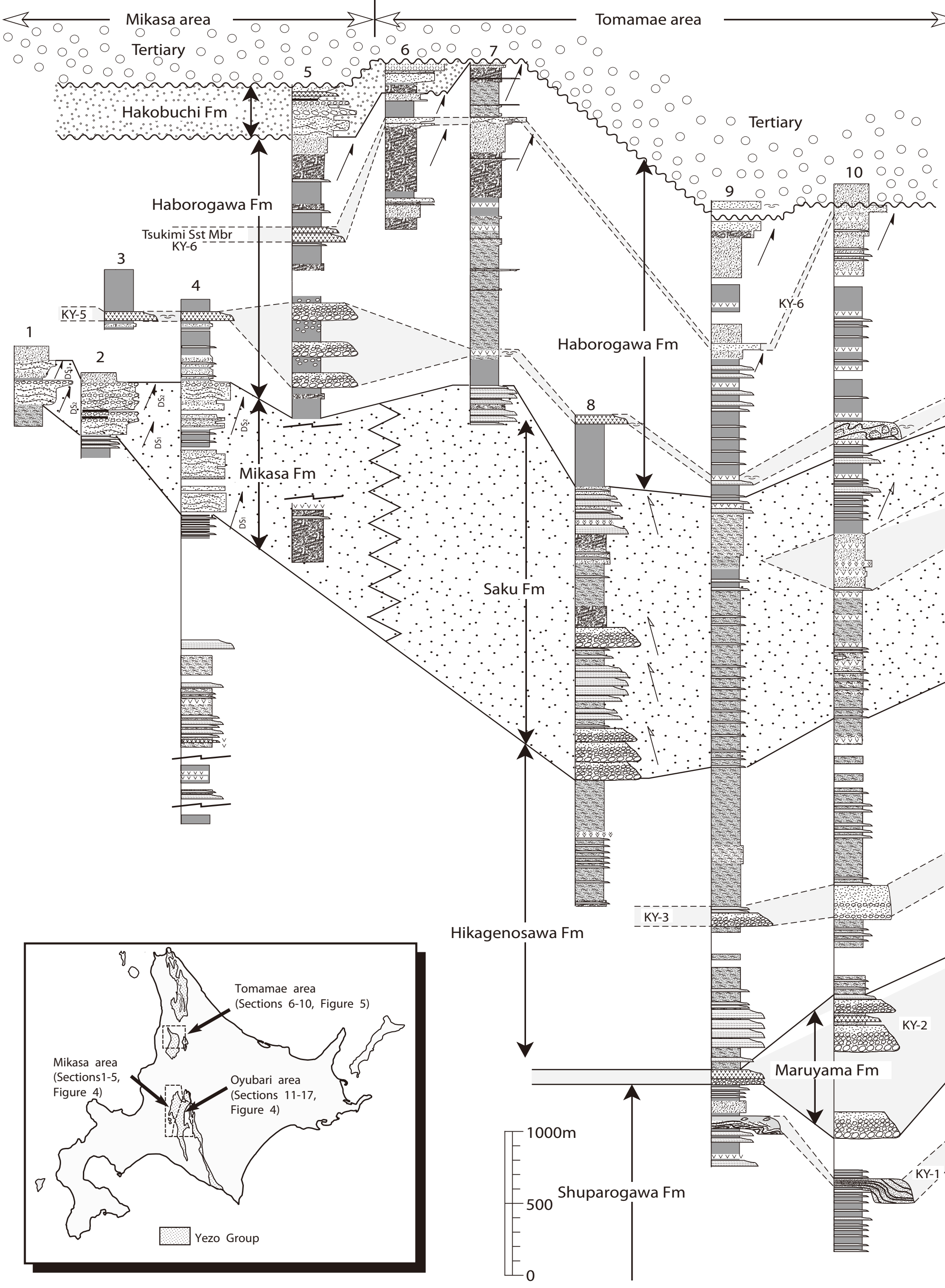

Figure 6, Takashima et al. 


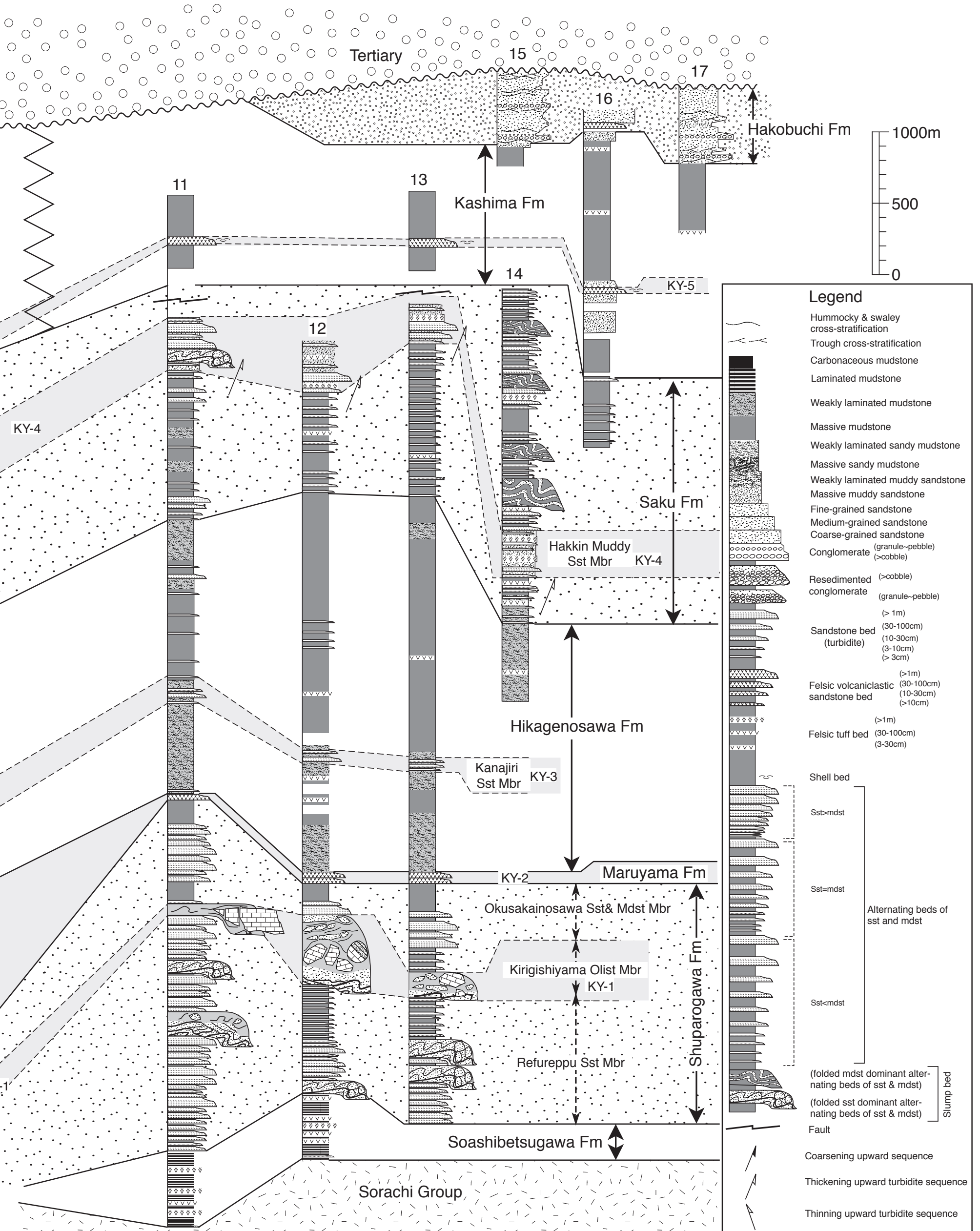



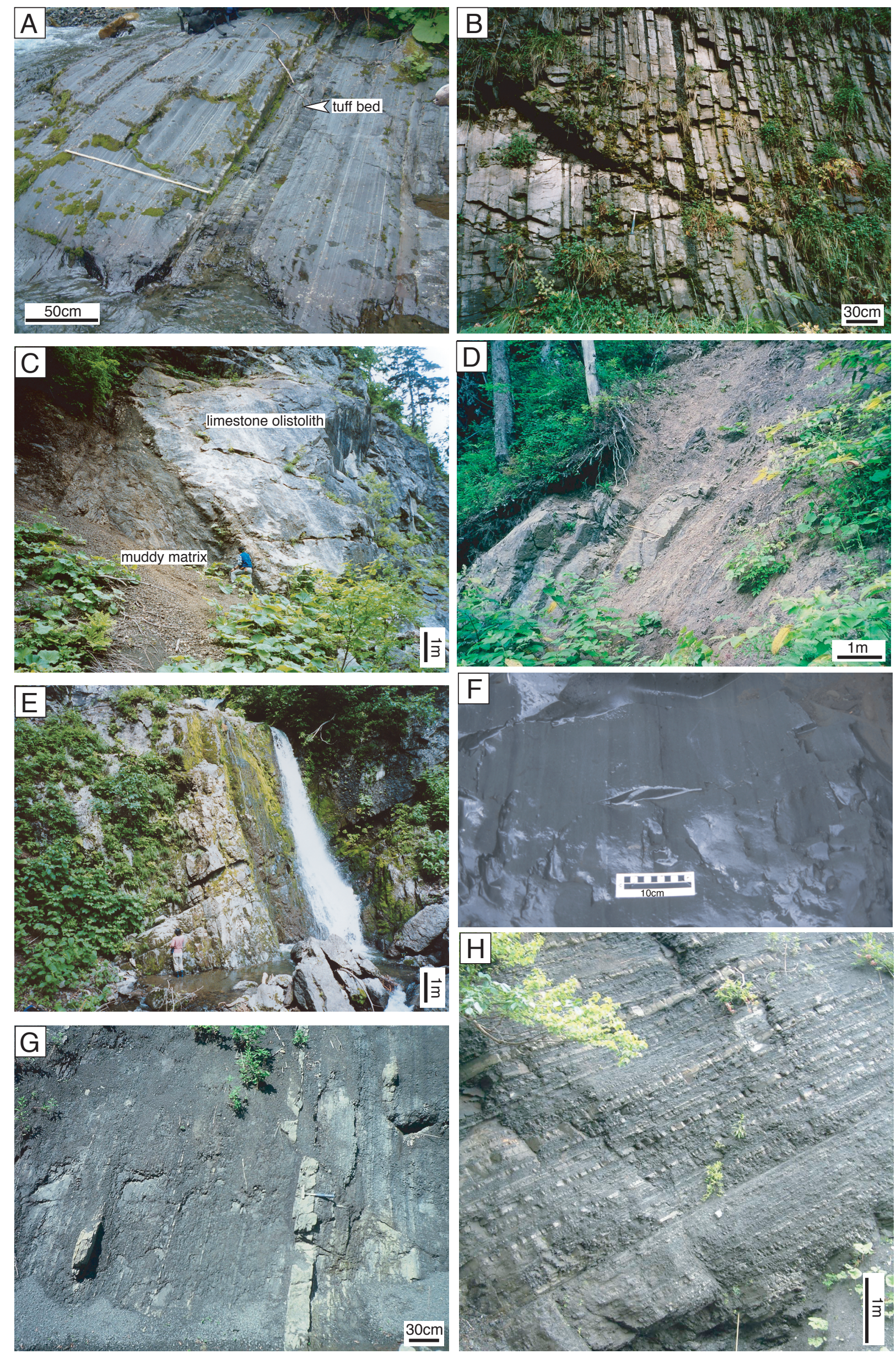

Figure 7, Takashima et al. 

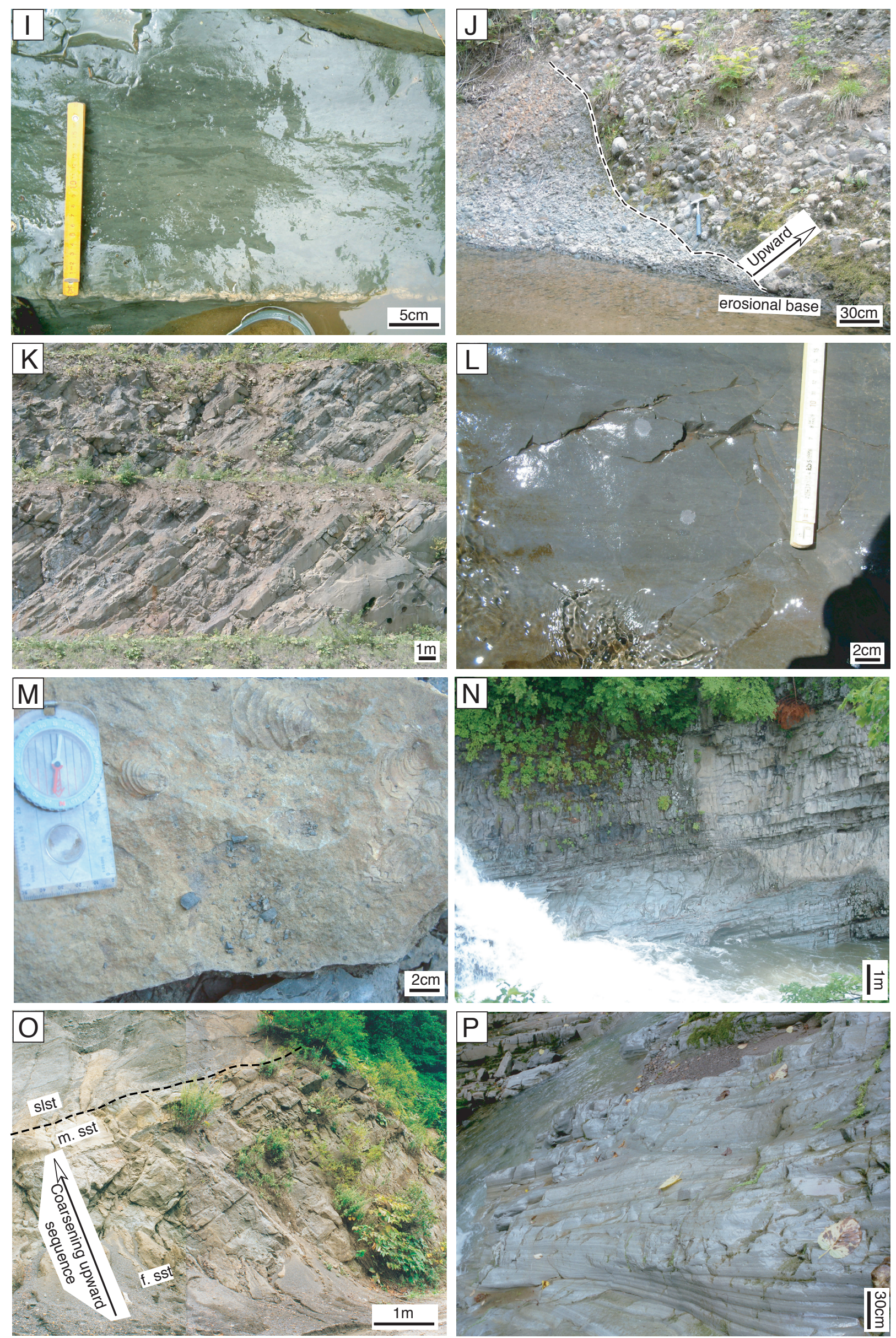

Figure 7, Takashima et al. 


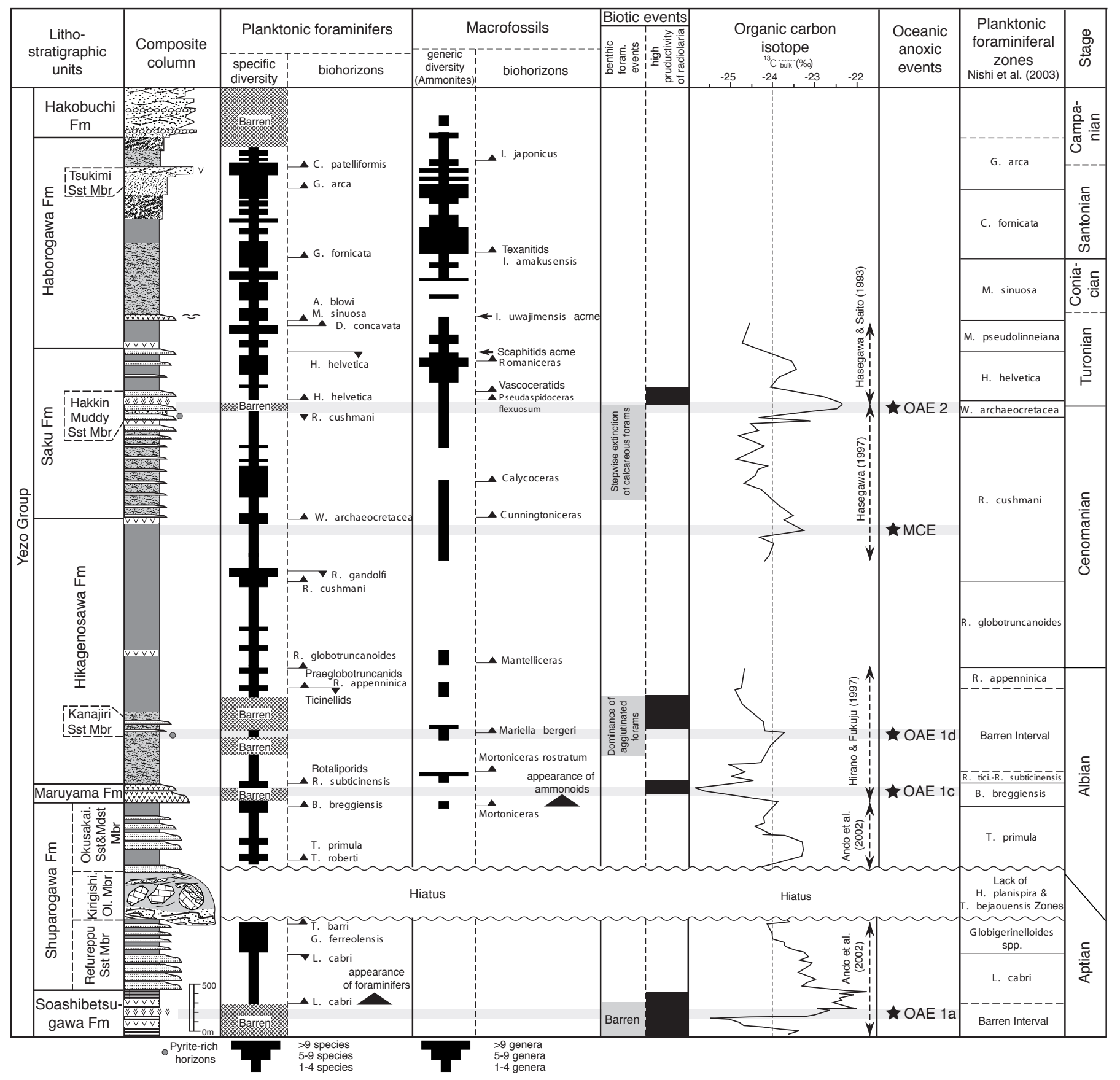

Figure 8, Takashima et al. 


\begin{tabular}{|c|c|c|c|c|c|}
\hline KY-6 & $10-30 \mathrm{~m}$ & Tuffaceous coarse sandstone beds & $\begin{array}{l}\text { Middle parts of the Kashima } \\
\text { and Haborogawa Formations } \\
\text { (Tsukimi Sst Mbr) }\end{array}$ & Latest Santonian & Fig. $7 \mathrm{~N}, \mathrm{O}$ \\
\hline KY-5 & $10-20 \mathrm{~m}$ & $\begin{array}{l}\text { Green tuffaceous coarse sandstone beds with } \\
\text { abundant I. uwajimens is }\end{array}$ & $\begin{array}{l}\text { Lower parts of the Kashima } \\
\text { and Haborogawa Formations }\end{array}$ & Early Coniacian & Fig. 7M \\
\hline KY-4 & $<300 \mathrm{~m}$ & $\begin{array}{l}\text { Greenish gray tuffaceous muddy sandstone } \\
\text { with abundant P lanolites trace fossils and } \\
\text { very thick felsic tuff beds }\end{array}$ & $\begin{array}{l}\text { Middle part of the } \\
\text { Saku Formation } \\
\text { (Hakkin Muddy Sst Mbr) }\end{array}$ & Early Turonian & Fig. 7I \\
\hline $\mathrm{KY}-2$ & $<82 \mathrm{~m}$ & Felsic tuff and tuffaceous sandstone beds & Maruyama Formation & Early Late Albian & Fig. 7E \\
\hline $\mathrm{KY}-1$ & $<400 \mathrm{~m}$ & $\begin{array}{l}\text { Olistostrome or debris flow deposits occasionally } \\
\text { containing "Orbitolina" limestone blocks }\end{array}$ & $\begin{array}{l}\text { Middle part of the } \\
\text { Shuparogawa Formation } \\
\text { (Kirigishi. Olistostrome Mbr) }\end{array}$ & $\begin{array}{l}\text { Late Aptian- } \\
\text { Early Albian }\end{array}$ & Fig. 7C \\
\hline
\end{tabular}

Table 1, Takashima et al. 